\title{
TÉMATA PRO VZDĚLÁVACÍ LEKCE SENIORŮ V KNIHOVNÁCH: VÝSLEDKY KVANTITATIVNÍHO ŠETŘENÍ
}

\section{TOPICS FOR EDUCATIONAL LESSONS OF SENIORS IN LIBRARIES: RESULTS OF QUANTITATIVE SURVEY}

\author{
Iva Zadražilová \\ Moravská zemská knihouna
}

\begin{abstract}
Abstrakt
Účel - Záměrem šetření, jehož výsledky jsou předkládány v této výzkumné studii, bylo získat informace o kompetencích seniorů v oblasti informační gramotnosti a o jejich zájmu o vzdělávání v různých tématech, která se týkají práce s internetem a s ICT. Hlavní výzkumná otázka byla zaměřena na zjištění témat, ve kterých se senioři chtějí vzdělávat.

Design/metodologie/přístup - Tento výzkum je součástí empirické části disertační práce autorky a navazuje na již publikované výsledky kvalitativního výzkumu potřeb seniorů v práci s internetem. Získané výsledky bylo následně zapotřebí ověřit na úrovni zobecnitelnosti pomocí kvantitativního výzkumu, pro který byla zvolena forma dotazníkového šetření a v rámci kterého se podařilo získat více než 750 responzí. Výzkumný design byl nastaven na parametry aplikovaného výzkumu a kvantitativní šetření bylo jednou $\mathrm{z}$ jeho součástí.

Výsledky - Výzkum ukázal, že senioři mají obecně velký zájem se vzdělávat, a to i prostřednictvím knihoven. Témata, která jsou pro ně zajímavá, častěji souvisí přímo s prací s obsahem (nap̌r. úprava fotografiî), než s používáním softwaru a ovládáním nástrojů typu e-mail, textové editory apod. Současně deklarují poměrně velkou míru kompetencí v každodenních činnostech prováděných prostřednictvím internetu a technologií.

Originalita/hodnota - Vzhledem k faktu, že proces vzdělávání seniorů v knihovnách není řešen rámcově a systematicky a každá knihovna si připravuje lekce sama, bylo deset témat, která vzešla z výzkumu, didakticky zpracováno do vzdělávacích lekcí. Tato metodická př́ručka je volně dostupná přes portál eknihy.knihovna.cz a má ambice stát se praktickým návodem nejen pro knihovníky, ale i další instituce, které se vzděláváním seniorů zabývají.
\end{abstract}

Klíčová slova: senioři, digitální propast, knihovny, vzdělávání, informační gramotnost, internet, metodika

\begin{abstract}
Purpose - The aim of the survey which is presented in this research study, was to obtain information on senior literacy competences in the field of information literacy and their interest in learning on various topics related to Internet and ICT work. The main research question was focused on finding the topics in which seniors want to be educated.

Design/Methodology/Approach - This research is a component of the empirical part of the dissertation thesis and is based on already published results of qualitative research that examined the needs of seniors in the work with the Internet. The obtained results were subsequently verified on the level of generalizability by means of quantitative research. The questionnaire survey obtained more than 750 responses. The research design was set to the parameters of applied research and quantitative research was one of its sections. Results - Research has shown that seniors are generally very interested in learning through the libraries network. Topics that are interesting to them are more often related to content (such as editing photos) than to using software and using e-mail, text editors, etc. At the same time, elderly people declare a relatively high degree of competence in everyday internet activities and technology.
\end{abstract}


Originality/Value - Due to the fact that the process of education of seniors in libraries is not dealt with in a general and systematic manner and each library prepares lessons itself, ten topics that emerged from the research were didactically transformed into educational lessons. This methodical guide is freely available through eknihy.knihovna.cz portal and has the ambition to become a practical guide not only for librarians but also for other institutions dealing with senior education.

Keywords: seniors, digital divide, libraries, education, information literacy, internet, methodology

\section{Úvod}

Seniơ̌i tvoři dnes jednu z nejpočetnějších skupin návštěvníků knihoven, zejména co se týká knihoven veřejných (Richter, 2014). Využití sítě veřejných knihoven je jednou z možností zajištění vzdělávání seniorů. Nejvýraznější podíl tvoři senioři ve skupině ekonomicky neaktivních návštěvníků knihoven (27\%) a současně z kategorie seniorů 60 až 69 let navštěvuje knihovny 38 \% lidí (Richter, 2014). Čtenáři z řad seniorů využívají knihovny nejen jako místa půjčování knih, ale také jako přirozená místa setkávání, která jim nabízí príležitost zúčastnit se různých typů akcí. Knihovny se též často mohou setkat s poptávkou po vzdělávacích akcích, kterou tato cílová skupina sama vyjadřuje. Mnoho knihoven se postupně mění na komunitní centra a často suplují poptávku seniorů po klubech důchodců nebo útočišti, kde se mohou nejen setkávat, ale také být součástí aktivit v místě svého bydliště. Komunitní funkce tak vzrůstá jak v kulturní, tak ve vzdělávací oblasti. Knihovny jsou tedy dnes právem považovány za vzdělávací instituce a nepostradatelný článek v realizaci procesu celoživotního učení. Knihovna je na mnoha místech jediným obecně dostupným kulturním zařízením. Je to dáno i tím, že pokrytí knihoven v České republice je nejhustší na světě. Na každých 1971 obyvatel pripadá jedna knihovna, což tvrdí výsledky výzkumu nadace manželů Gatesových (Quick, 2013).

Důvodů výběru knihoven jako přirozených aktérů vzdělávacích akcí pro seniory existuje mnoho a daly by se stručně shrnout do následujících bodů (Novotná, 2013):

- Knihovny jsou pro seniory dostupné, finančnè nenáročné

- Knibovny json privietivé a bespečné, senioruim známé

- Knibovny poskytují celoživotni vęeèlávání, zpprostrédkovávají setkávání

- Knihovny umožñují veřejnosti př̌stup k informačnim a komunikačnim technologiim

- Knibovny json znalci mistni správy a dalšich organizací a instituci v mistě a umí vytipovat a oslovit aktivni osobnosti $v$ obci

- Knibovny podporuji výmènu informací

- Knibovny jsou součástí širř̌ sité, mají jasnou strukturu s dostatečným množstvím kvalifikovaných a žkušenjých pracovnikì, umi komunikovat a maji dostatek praktických zkušeností s prípravou a realizaci projekti.

Každý z těchto bodů je pro cílovou skupinu seniorů velmi důležitý. Z hlediska nabídky vzdělávání se jeví jako podstatná zejména dostupnost knihoven, bezpečné prostředí, ve kterém se senioři cítí pohodlně, a taktéž důvěra $\mathrm{v}$ knihovníky jako průvodce vzděláváním. 
Mnoho knihoven, zejména na městských a krajských úrovních, se práci se seniory aktivně věnuje. Za posledních několik let vzniklo množství akcí, které jsou zaměřeny na tuto cílovou skupinu (Stluková, 2015). Využíván je i koncept výše zmíněných komunitních knihoven, organizují se semináře na míru pro konkrétní publikum, pořádají se praktické workshopy nebo se zvou odborníci na besedy. Dle aktuální situace v knihovnách ČR je ovšem zapotřebí konstatovat, že vzdělávání cílové skupiny seniorů v knihovnách zatím probíhá více méně náhodně. Nejsou $\mathrm{k}$ dispozici metodiky, které by se daly využít plošně a které by knihovníkům pomohly v plánování jejich vlastních lekcí. Přesto, že v rámci Sdružení knihovníků a informačních pracovníků (SKIP) existuje Sekce 60+, zabývající se problematikou vzdělávání seniorů $\mathrm{v}$ knihovnách, stále chybí platforma, kde by knihovny mohly sdílet své nápady, témata a zkušenosti v práci s touto cílovou skupinou.

Pokud se tedy knihovna rozhodne, že přichystá nabídku vzdělávacích lekcí přímo pro seniory, musí se zároveň zamyslet nad tím, jaká témata jsou pro ně zajímavá. Obsah lekce bývá často jedním z rozhodujících faktorů, který seniory do knihovny přivede (Mazurová, 2016). Podle průzkumu (Kočí, 2012) jsou mezi českými seniory nejčastěji vyhledávané oblasti informací počasí, př́roda, politika, sport, informace o zdraví, vaření a výživa, historie, technika, církevní dění, kultura a cestování. Jedním z důležitých závěrů tohoto průzkumu je, že aktivní vztah k informacím a internetu je rozhodujícím faktorem pro jejich úspěšné vyhledávání. A nejde jen o samotné nalezení informací - základem informační gramotnosti je rozpoznání potřeby získání určité informace, její vyhledání, vyhodnocení a efektivní využití. Těmto dovednostem je potřeba naučit, nebo alespoň ukázat cestu, jak se ve světě informací orientovat a jak s dnešním nadbytkem informací umět zacházet tak, aby to přineslo požadovaný výsledek. Plošně již není nutné řešit dostupnost technologií, ale zejména to, jak je efektivně využívat pro práci s informacemi.

$\mathrm{Na}$ základě těchto skutečností bylo cílem níže popsaného výzkumu zjistit, v jakých tématech se čeští senioři chtějí vzdělávat. Kvantitativní šetření mělo přinést odpovědi na konkrétní otázky týkající se zájmu o vzdělávání, kompetencí informační gramotnosti této cílové skupiny a také preferencí témat. 


\section{Metodologie kvantitativního výzkumu}

\subsection{Výzkumné otázky}

Cílem výzkumu bylo získat informace o kompetencích seniorů v oblasti informační gramotnosti a o jejich zájmu o vzdělávání v různých tématech. Hlavní výzkumná otázka tedy byla stanovena následovně:

\section{HVO: V jakých tématech z oblasti informační gramotnosti se chtějí senioři vzdèlávat?}

Na základě této výzkumné otázky a v návaznosti na hlavní cíl práce byla stanovena hypotéza:

H: Oblasti, ve kterých se chtějí senioři vzdělávat, souvisí častěji s prací s obsahem než s ovládáním nástroje.

Pro lepší specifikaci proměnných byly stanoveny i dílčí výzkumné otázky.

DVO1: Jakou maji senioř úroveň kompetenci v oblasti informační gramotnosti? Existuje rozdíl mezi seniory, kteř̀ se

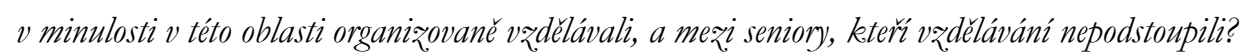

Tato výzkumná otázka byla formulována na základě výsledků kvalitativního výzkumu (Zadražilová, 2017), kdy z rozhovorů vyplynulo, že senioři se často odvolávali na kurzy z oblasti počítačové či informační gramotnosti, které absolvovali, a uváděli, že jim tyto znalosti pomohly v dalších činnostech. Dá se tedy usuzovat, že pokud respondent prošel nějakým organizovaným neformálním vzděláváním, bude své dovednosti hodnotit lépe než respondent, který se žádného vzdělávání neúčastnil.

DVO2: Liši se hodnoceni dovedností v pouřiviání informačnich a komunikačnich technologii dle věku?

Vzhledem $\mathrm{k}$ faktu, že senioři mladších ročníků použivali ICT a internet často ještě $\mathrm{i}$ v rámci svého pracovního života, lze očekávat, že budou hodnotit svoje dovednosti lépe než starší respondenti.

DVO3: Jak velký mají seniori zájem o zyyšrováni svých kompetenci informačni gramotnosti z blediska práce s obsabem a z. blediska ovládání nástroje?

Tato výzkumná otázka vychází z principu v rozdílu mezi operačními a formálními dovednostmi a dovednostmi komunikačními, informačními a vytvářením obsahu. Toto rozdělení odráží i problematiku sekundární digitální propasti, která je zaměřena více na dovednosti než na práci s obsahem.

DVO4: Je mo:̌nnost vąèlávání prostřednictvím knihoven pro seniory zajímavá?

Za touto výzkumnou otázkou stojí opět rozhovory se seniory, kteř́ uváděli, že by uvítali nabídku ucelených vzdělávacích kurzů, kam budu pravidelně docházet a které budou moct absolvovat $\mathrm{v}$ institucích, které mají v blízkém dosahu, napríklad v knihovnách.

Pro určení těchto podotázek a jejich přenesení do dotazníku jsem vycházela nejen ze svých zjištění, ale také ze strategického dokumentu nazvaného Strategie digitální gramotnosti ČR na obdobi 2015-2020 (MPSV, 2015). Tento dokument reaguje na změny, které ve společnosti probíhají na základě globální penetrace informačních a komunikačních technologií a na základě zpracování informací a práce s informacemi obecně. 
Strategie digitální gramotnosti také definuje kompetenční dimenzi, kterou řadí pod oblast digitální gramotnosti, a uvádí, že tato kompetence ,je soubrnem dillǔch osvojených digitálnich kompetencí, které se vątabuji k.

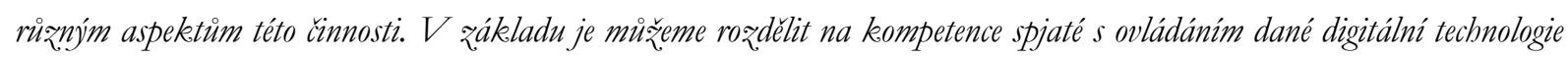
(počitače, probližeče internetu, dotykové obrazovkey atp.) a na kompetence vątabujicí se na práci s obsahem - práce s informacemi, online komunikace a vytvárení obsabu. "(MPSV, 2015). Kompetence, které zobrazuje níže uvedená tabulka, jsou rozdělené na dovednost ovládání samotné technologie a dovednost práce s obsahem. Podobné dělení je možné nalézt ve výzkumech digitálních dovedností (Van Deursen, 2018), (St. Jean, 2012) a tyto kompetence byly velmi důležitým vodítkem při zjišt'ování schopností respondentů.

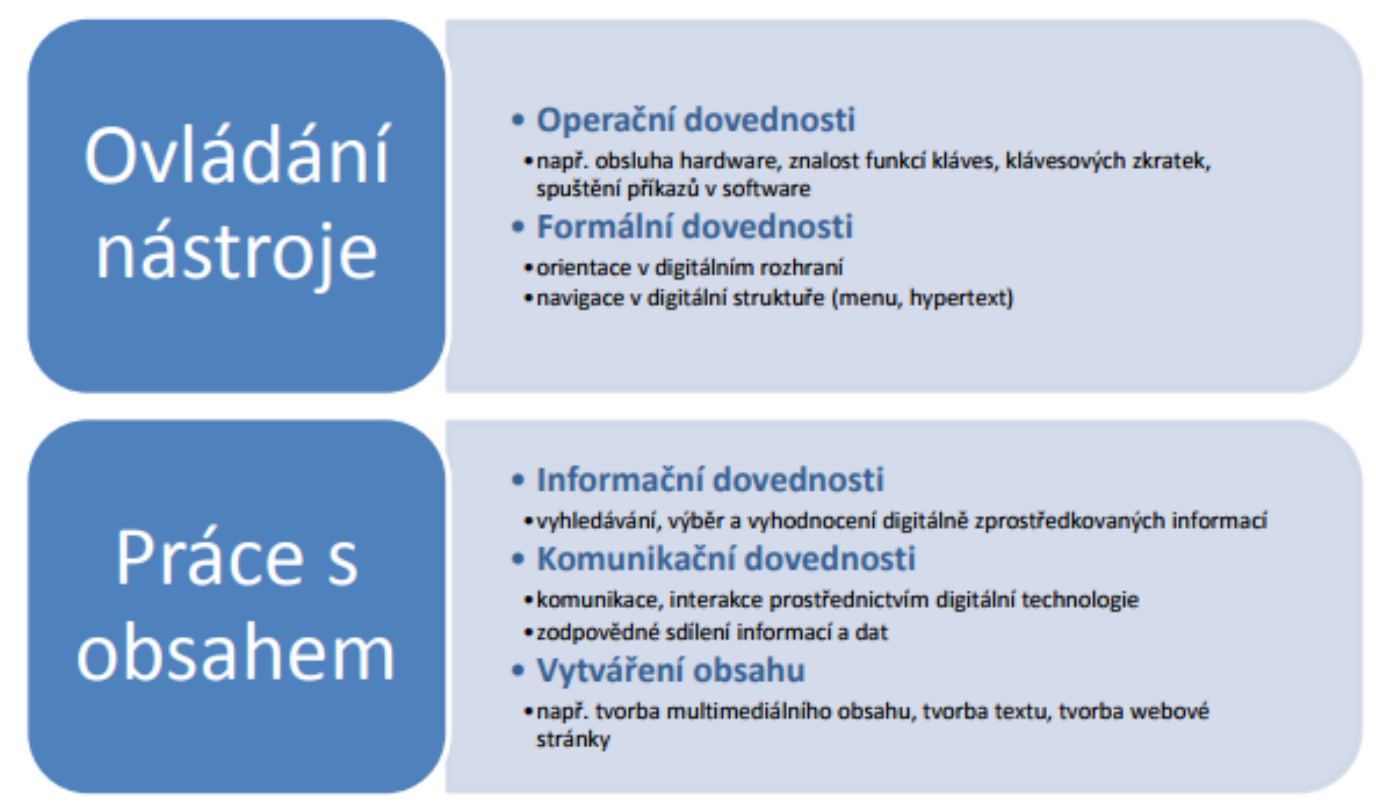

Obr. 1 Dimenze digitálních dovedností

\subsection{Procedura sběru a zpracování dat}

Jako základní nástroj sběru dat byl zvolen dotazník vytvořený v online nástroji Google Formuláře. Papírová (tišsěná) forma dotazníku př́stupná nebyla. Dotazník byl zpř́istupněn cca tři týdny vobdobí 17. 1. - 7. 2. 2018.

Dotazník obsahoval celkem 27 otázek, členěných do kategorií Dovednosti, Zkušenost se vzděláváním, Témata a Demografické otázky. Dotazník byl anonymní, a kromě první otázky, ve které jsem se ptala na splnění věkové podmínky, byly všechny další otázky nepovinné. Součástí dotazníku bylo úvodní oslovení respondentů s vysvětlením, kdo jsem, proč tato data sbírám a k jakému účelu budou využita.

Před spuštěním samotného testování byla provedená pilotáž dotazníku, které se zúčastnili 4 vybraní senioři. Pilotáž měla potvrdit nosnost výzkumného nástroje a jejím cílem bylo zjistit, zdali dotazník funguje, není-li př́liš dlouhý, zmatený apod. Nechala jsem seniory otevrút dotazník a požádala je, aby jej vyplňovali a nahlas komentovali své počínání. Veškeré jejich připomínky jsem si zapsala, podrobila analýze a na základě této 
zpětné vazby následně dotazník upravila tak, aby více reflektoval způsob myšlení a porozumění cílové skupiny, které byl určený, a také aby byla podchycena logika dotazníku, srozumitelnost otázek atd.

Po ukončení sběru dat jsem získala 758 vyplněných dotazníků, po vyřazení těch respondentů, kteří nesplňovali minimální věkovou hranici, zbylo 722 responzí. Data byla z Google Formulářủ převedena do souboru v programu MS Excel, kde byla vyčištěna a následně zpracována pomocí tabulek a grafů.

\subsection{Participanti výzkumu}

Participanti výzkumu museli splňovat dvě kritéria, a to kritérium věkové a kritérium ovládání počítače. Splnění první podmínky bylo obsaženo hned v první filtrovací otázce, kde respondenti potvrzovali, zdali je jim 65 a více let. Tato věková hranice byla určena pro definici pojmu senior. Osoby, které tohoto věku nedosáhly, nemohly ve vyplňování dotazníku pokračovat. Druhá podmínka byla zajištěna tím, že dotazník se širíil výhradně v online prostředí a vyplnit jej mohly tedy pouze osoby s př́stupem na internet.

Distribuce dotazníku probíhala pomocí nepravděpodobnostního výběru metodou snowball (Miovský, 2003), a to několika různými cestami. Na začátku jsem oslovila přes mail seniory, se kterými jsem byla v minulosti v pracovním kontaktu a měla jsem od nich souhlas s použitím jejich e-mailu pro poslání dotazníku. Stejný mail jsem poslala své rodině a známým. Následně jsem umístila výzvu s prosbou o vyplnění dotazníku na svůj soukromý účet na Facebooku, respektive jsem požádala své přátele, aby dotazník poslali svým rodinným př́slušníkům, kteří splňují požadovaná kritéria. Dalším krokem bylo rozeslání mailu s odkazem na dotazník do diskusní mailové konference Knihovna, jejímž jsem členem. Současně jsem provedla rešerši a cíleně oslovila několik desítek organizací, které se seniorům věnují, a opět je požádala o šíření odkazu na dotazník. Mnohé z těchto organizací vyvěsily mou prosbu na své facebookové stránky, další informovaly své členy. Ve všech mých osloveních byla vždy zřetelně formulována prosba o další šíření odkazu na dotazník předpokládaným respondentům. Vše probíhalo v souladu s GDPR.

\subsection{Limity výzkumu}

V České republice žilo na konci roku 2018 celkem 2086617 osob ve věku 65 a více let (ČSÚ, 2018) a dle rozsahu získaného výběrového souboru (722 osob) by mohl být tento výzkum považován za reprezentativní. Realizovaný výzkum nicméně neměl ambice reprezentativního šetření, výsledky proto nelze zobecňovat na celou populaci. A to nejen z důvodu nevyváženého zastoupení vzorku v pohlaví a dosaženém vzdělání, ale také proto, že se zaměřoval pouze na aktivní uživatele internetu. Dalším důvodem byla i metoda výběru respondentů, kdy nebylo v mých možnostech realizovat kvótní výběr, a respondenty jsem získala metodou sněhové koule, která není vhodným nástrojem pro výběr reprezentativního vzorku.

Z důvodu předpokládané nereprezentativnosti vzorku proto nebyly kromě hlavní hypotézy stanoveny další, které je nutné vyhodnocovat statisticky na úrovni pravděpodobnosti s ohledem na výběrové chyby. Při vyhodnocení by nebylo možné spolehlivě tvrdit, že vyvrácení či potvrzení hypotéz má dostatečnou pravděpodobnost, kterou lze následně zobecnit na populaci. Proto byla určena jen jedna hypotéza, jejíž 
ověřitelnost lze postavit na získaných datech. Na výzkumné otázky jsou předneseny odpovědi, které byly zpracovány dle výsledků z dotazníku bez ohledu na jejich statistickou pravděpodobnost.

V českém prostředí se ovšem jednalo o jeden z prvních výzkumů tohoto druhu. Nebylo proto možné navazovat na relevantní data ke zkoumané problematice. Vzhledem k poměrně vysokému číslu responzí je možné získaná data použít pro další podrobná šetření s ambicemi reprezentativních výzkumů.

\section{Výsledná zjištění kvantitativního šetření}

\subsection{Demografie vzorku}

Na otázku pohlaví odpovědělo celkem 720 respondentů. Z toho bylo 585 žen (80,8 \%) a 132 mužů (18,3 \%). 6 respondentů zvolilo možnost Nechci odpovědět.

\section{Pohlaví respodentů}

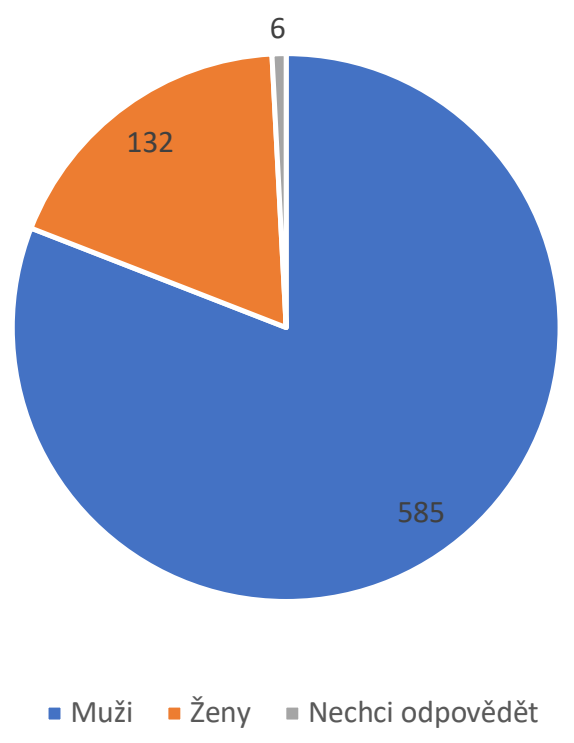

Graf 1 Poblaví respondenti

Ve složení respondentů je tedy více žen. Průměrný rok narození respondenta je rok 1946, jednalo se tedy o člověka ve věku 72 let. Nejvíce respondentů bylo narozeno v roce 1950, jednalo se o osoby ve věku 68 let. Věková křivka je dobře patrná v níže uvedeném grafu.

Z hlediska regionálního rozložení bylo nejvíce respondentů z Jihomoravského kraje (18,3 \%), dále z Prahy $(17,7 \%)$, Jihočeského kraje (10,6 \%), Středočeského a Ústeckého kraje (shodně 8,2 \%). Nejméně respondentů se nacházelo v kraji Vysočina (2\%) a ve Zlínském kraji (2,6\%).

Více než třetina respondentů (34,4 \%) má trvalé bydliště v městě nad 100000 obyvatel. $14 \%$ respondentů žije ve městě s 20 000-49 999 obyvatel. Skoro čtvrtina (23,4 \%) respondentů ale žije v menších obcích s velikostí do 5000 obyvatel. 
V rámci výzkumu byla položena i otázka na nejvyšší dosažené vzdělání. Na tuto otázku odpovědělo 722 respondentů a největší množinu tvoři 271 lidí s ukončeným středoškolským vzděláním s maturitou (37,5\%). Následuje skupina vysokoškolsky vzdělaných osob. Tento stupeň dosaženého vzdělání uvedlo 226 jedinců, což je přibližně třetina (31,3\%) všech participantů. Následuje skupina 119 vyučených osob (16,5 \%), ale čtvrtou nejpočetněji zastoupenou skupinu tvoří lidé s nástavbovým vzděláním, tj. lidé, kteří mají maturitu a další druh vzdělání navíc (10,7\%). Osob se základním vzděláním bylo pouze 15 , což činilo $2 \%$. Zajímavé je, že výsledky ukázaly, že čím vyšší rok narození respondenta, tím menší zastoupení nižších stupňủ vzdělání, což dobře ukazuje následující graf.

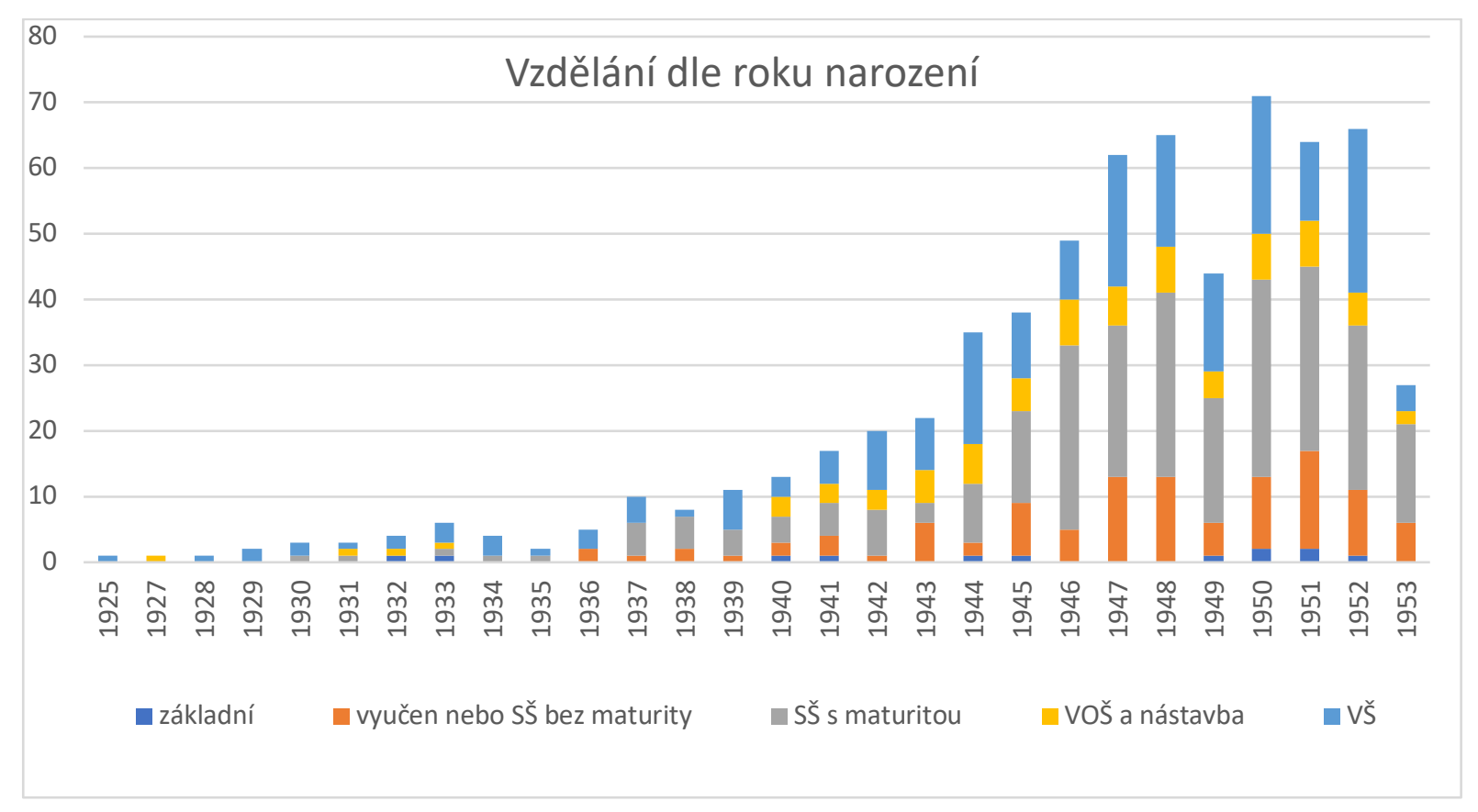

Graf 2 V żèlanostni struktura respondent

Výsledky realizovaného výzkumu neodpovídají celkovému zastoupení dosažené výše vzdělání v populaci osob nad 65, což je patrné při porovnání s procentuálními údaji z posledního sčíání lidu v roce 2011 (ČSÚ, 2012). Údaje jsou uvedeny v procentech a k číslům za rok 2011 jsem přidala i věkovou kategorii 60-64 let, která mezitím dosáhla vyššího věku. Zbylá procenta připadají na osoby s nedokončeným vzděláním nebo jiným typem vzdělání.

\begin{tabular}{|l|c|c|c|c|c|}
\hline & Základní & Vyučení & Střední s maturitou & Nástavbové & Vysokoškolské \\
\hline Výzkum & 2,1 & 16,5 & 37,5 & 10,7 & 31,3 \\
\hline ČSÚ & 25 & 36,6 & 21,6 & 4,3 & 9,3 \\
\hline
\end{tabular}

Tabulka 1 Srovnáni procentuálního zastoupeni úrovni vædèláni osob nad 65 let

Tuto disproporci je možné vysvětlit pravděpodobnou korelací mezi dosaženou výší vzdělání a používáním internetu. Jak ukazují statistiky (ČSÚ, 2018), (ČSÚ, 2017), s výší dosaženého vzdělání narůstá počet uživatelů internetu, bez ohledu na věkovou kategorii. 
Vliv na vyšší úroveň dosaženého vzdělání měla zřejmě i forma rekrutace respondentů, kdy byli neúmyslně získáni respondenti z podobně vzdělané sociální skupiny. Tuto skutečnost potvrzuje otázka směřující na poslední zaměstnání účastníků výzkumu. Nejvíce respondetnů uvedlo, že byli zaměstnáni jako učitelé (pedagogové), knihovníci, zaměstnanci státní správy, úředníci, technici nebo pracovali ve zdravotnicví (lékaři a zdravotní sestry). Jen pár desítek seniorů uvedlo, že pracovali jako dělníci, uklízečky nebo skladníci, což jsou profese, které obvykle nevyžadují vyšší úroveň vzdělání.

\subsection{Dovednosti}

První část dotazníku se týkala zjištění úrovně kompetencí seniorů, kdy měli sami hodnotit své dovednosti pomocí Lickertovy škály, která se užívá pro určení míry stupně souhlasu a nesouhlasu. Byla zvolena pětibodová stupnice. Současně byla přidána možnost Nevím, nedělám to, protože ne všichni respondenti např́klad používají klávesové zkratky a nemohli by vyjádřit svou míru souhlasu. Respondent měl určit, do jaké míry souhlasí s tvrzením ve formě kladného stanoviska (Nedèla mi problém, Umím).

Dovednosti byly rozděleny do pěti skupin, dle již zmiňované definice digitálních kompetencí, a v každé skupině byly předloženy tři činnosti.

V základních operačních dovednostech vykazovali senioři vysokou míru souhlasu v otázce, zdali umí zapnout počítač a spustit internet. Jedná se o úkony spojené se základní počítačovou gramotností a vzhledem $\mathrm{k}$ tomu, že ta byla od účastníků výzkumu požadována, výsledky nijak nepřekvapily. Problematičtěji se jevila jen dovednost použití klávesových zkratek, přesto ale více než polovina seniorů vyjádřila názor, že je bez problémů používají. Přibližně desetina respondentů ale klávesové zkratky nezná a nepoužívá.

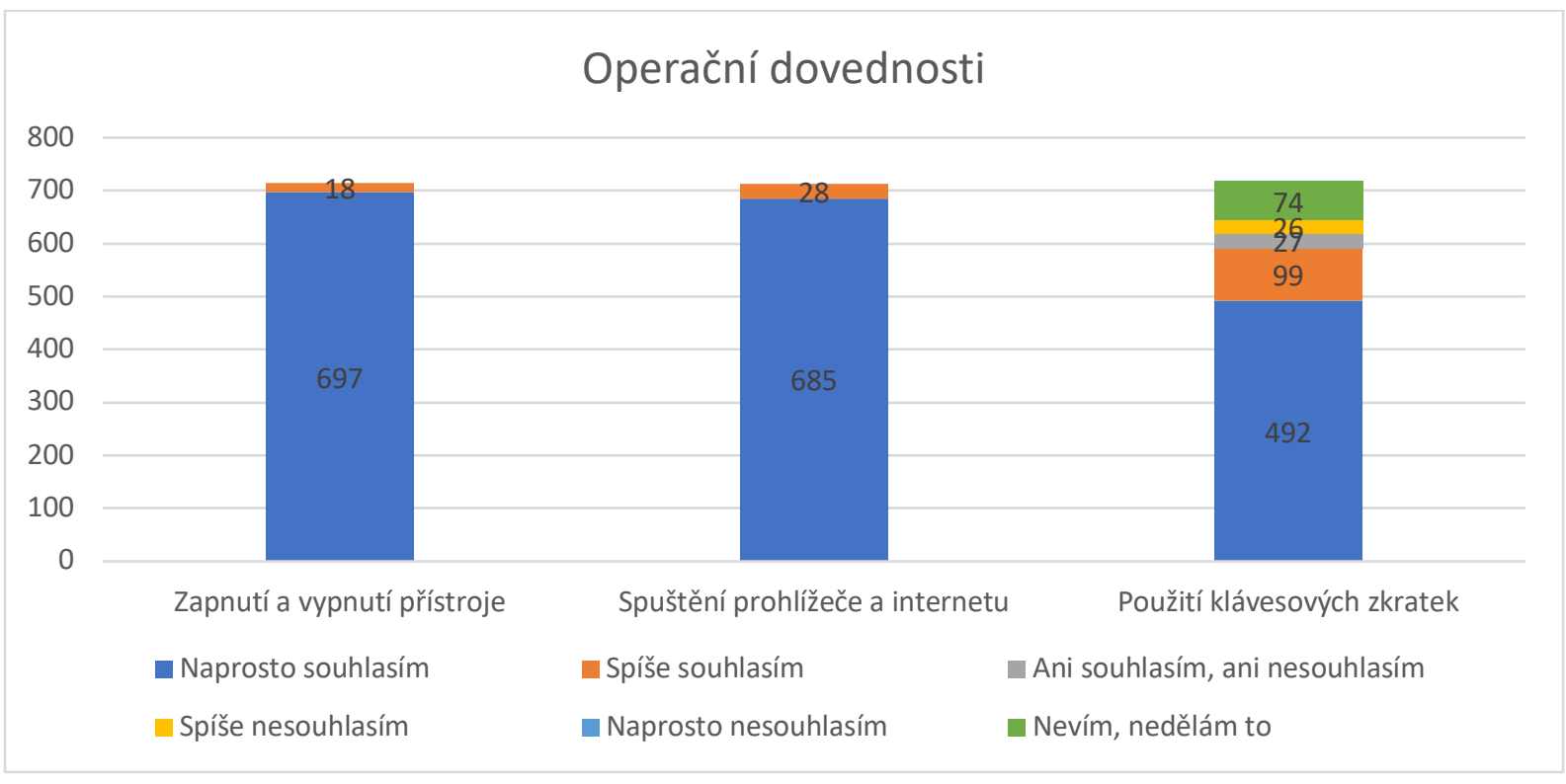

Graf 3 Operačni dovednosti

Mezi formálními dovednostmi činilo respondentům nejmenší problém zobrazení požadované webové stránky. Dovednost zadat do prohlížeče hledanou www adresu je samožrejmá pro téměř všechny 
respondenty. O něco hůre zvládají formátovat typ nebo velikost písma a ukládání obrazových dokumentů, zde se jedná o prúbližně čtvrtinu naprosto souhlasících seniorů méně než v př́ípadě zobrazení www stránky. Nicméně v obou př́padech přibližně desetina respondentů uvádí, že tuto činnost nedělá.

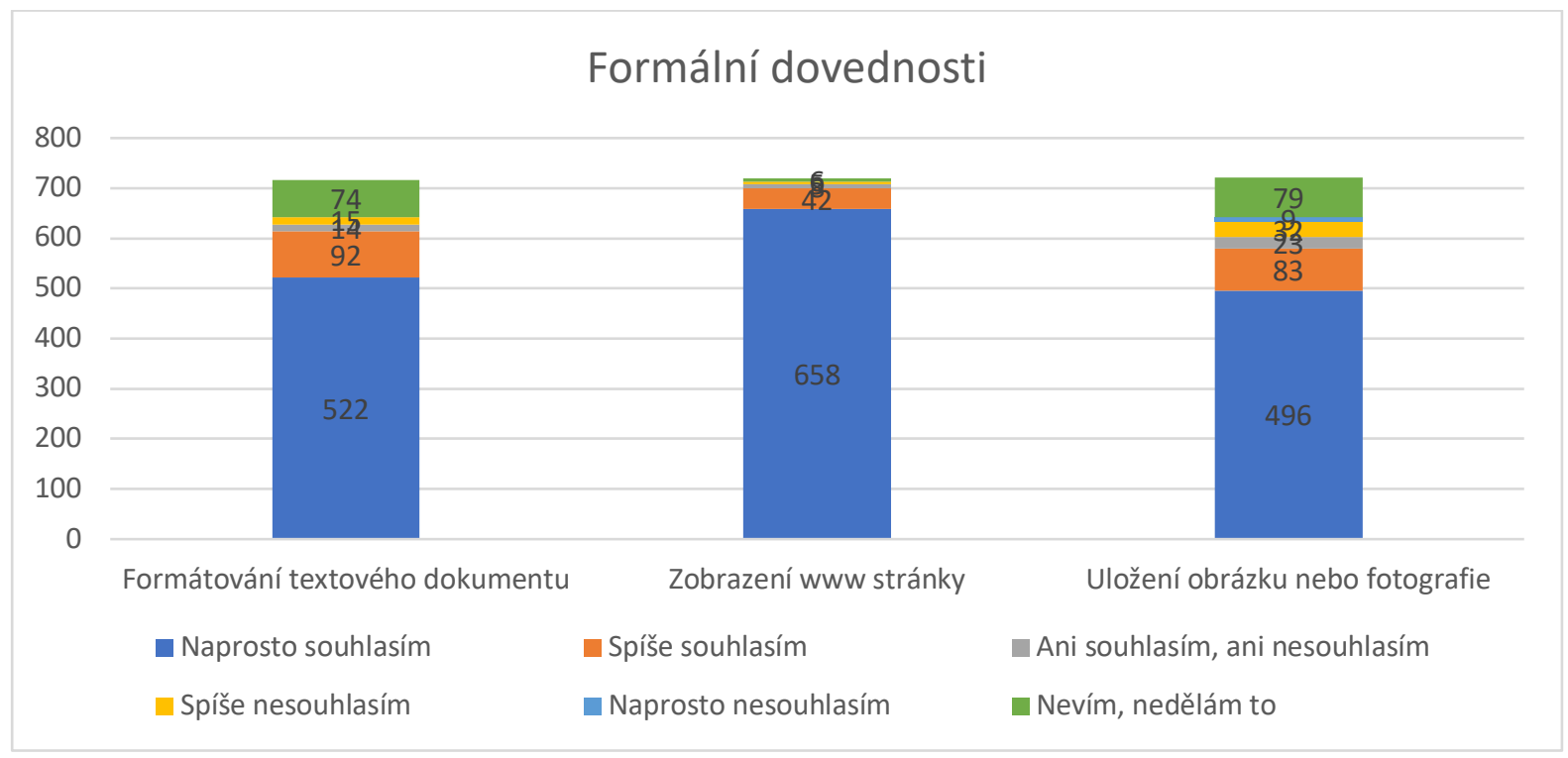

Graf 4 Formálni dovednosti

Jak je patrné z dalšího grafu, respondenti nemají problém s vyhledáním informací, které potřebují. To odpovídá $\mathrm{i}$ tomu, co uváděli v rozhovorech. $\mathrm{V}$ online předávání informací někomu dalšímu jsou si senioři také poměrně jistí. Velmi zřetelně se zde ale projevila disproporce mezi uspokojením informační potřeby a mezi schopností poznat, zdali je nalezená informace kvalitní. Touto dovedností si je zcela jista jen necelá polovina seniorů, zbytek vyjadřuje mírné pochybnosti, 39 osob se pohybovalo vintervalu nesouhlasu s tvrzením, že jim nedělá problém poznat, co je kvalitní informace a co ne.

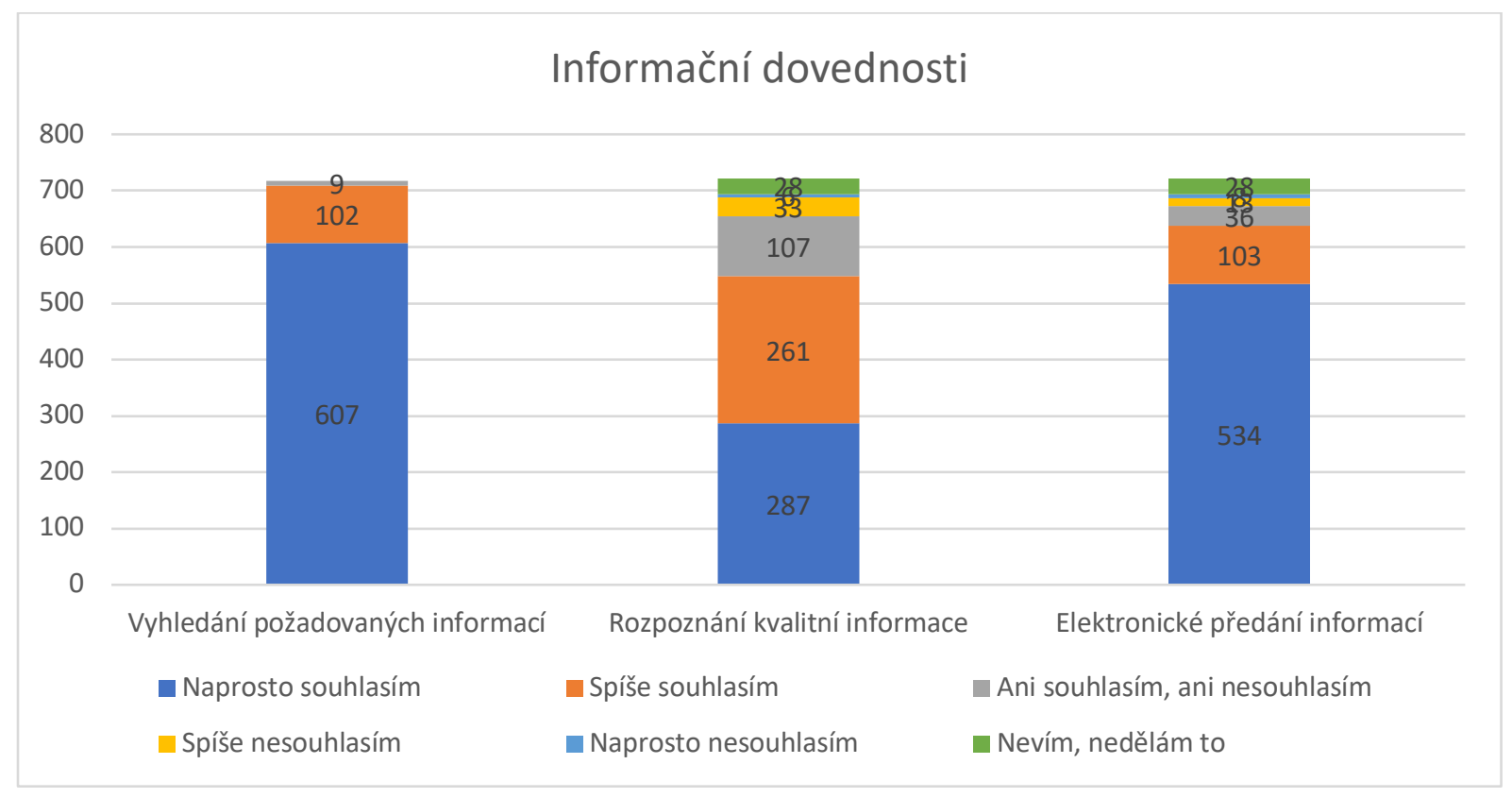


Mezi komunikační dovednosti bylo zařazeno použití mailu, telefonování a přeposlání obrázku nebo fotografie. Ukázalo se, že použití mailu je dovedností, u které je možné rúíct, že ji ovládají prakticky všichni dotazovaní. Po dovednosti zapnutí a vypnutí př́stroje, zkoumané v operačních dovednostech, je to počtem 688 naprosto souhlasných odpovědí druhá nejvíce ovládaná činnost. A jak ukazují naprosto a spíše souhlasné odpovědi, více než čtyřem pětinám seniorů nedělá problém do mailu přiložit fotografii nebo obrázek. Internetová telefonie je pro některé seniory už obtížnějším úkonem, každý pátý spíše a zcela nesouhlasí s tím, že by tuto činnost ovládal.

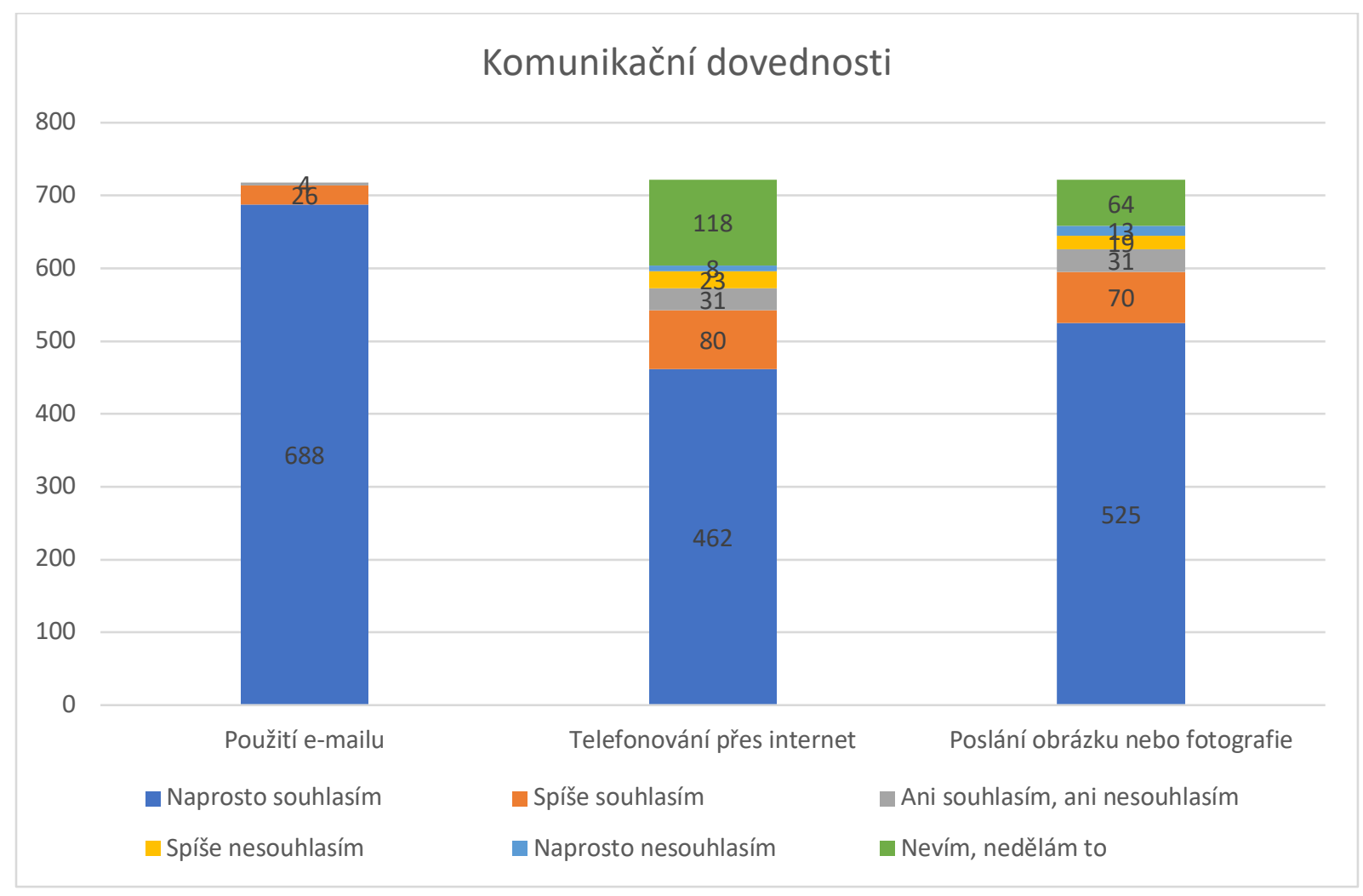

Graf 6 Komunikačni dovednosti

Oblast tvorby obsahu obecně vykázala nejnižší míru souhlasu s ovládáním jednotlivých činností a také nejvyšší množství těch, kteří se o umístění obsahu na internet ani nepokouší. Jedná se přibližně o třetinu dotazovaných. Každopádně i v tomto př́padě je v grafu vidět, že nejde o zcela neznámé činnosti, jelikož přibližně polovina dotazovaných je ovládá a tvrdí, že jim umístění fotografie, textu nebo dokonce videa na web problém nedělá. Že umí umístit video na web, si myslí 190 osob, což je asi každý čtvrtý senior. 


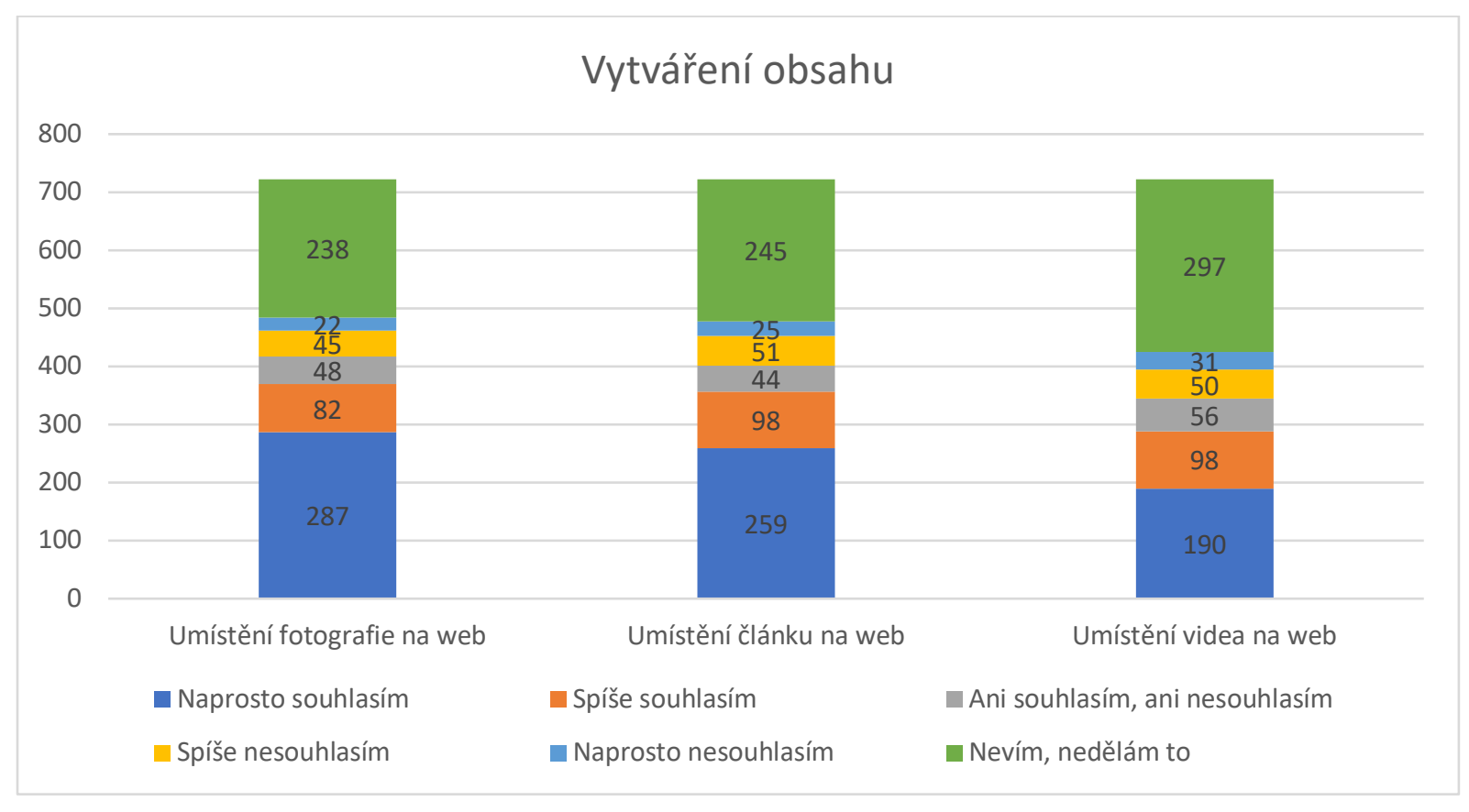

Graf 7 Vytvárení obsabu

\subsection{Zkušenost se vzděláváním}

Další otázky se týkaly předchozího, současného a budoucího vzdělávání. První otázka v této sekci zjišt’ovala, jak se respondenti naučili svým aktuálním dovednostem v užívání ICT a internetu. Jak je z výsledků patrné, skoro polovina respondentů získala svoje dovednosti za pomoci někoho dalšího a $\mathrm{k}$ tomu je možné přidat další skupinu, která se sice s počítačem naučila pracovat sama, ale s internetem jim někdo pomohl. V součtu se jedná o dvě třetiny všech osob (66,5\%). Tento výsledek opět odpovídá zjištěním z kvalitativní části výzkumu, že se senioři neobešli bez pomoci okolí, i když více než pětina participantů uvedla, že se těmto dovednostem naučila sama. V odpovědi Jinak respondenti zmiňovali, že jim pomohla školení v knihovnách, na U3V, počítačové kurzy apod. 


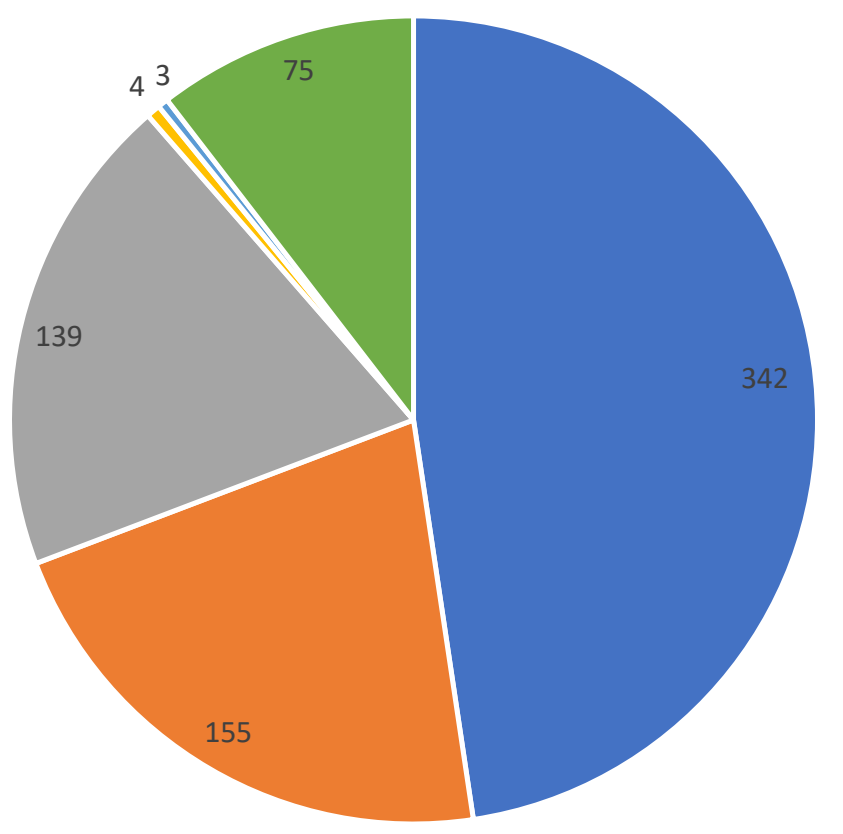

$$
\begin{aligned}
& \text { - S pomocí někoho dalšího } \quad \text { - Výhradně sám/sama } \\
& \text { — Na PC sám/a, s internetem mi pomohli — Nepamatuji se } \\
& \text { - V zaměstnání }
\end{aligned}
$$

Graf 8 Zkušenost se vzdéláváním

$\mathrm{Na}$ další otázku, týkající se formy pomoci se získáním dovedností, odpovídali jenom respondenti, kteří $\mathrm{v}$ předchozí otázce uvedli, že využili něčí pomoc. Mohli zde označit více odpovědí a také zde byla možnost Jinak. V této otázce se opět projevila výrazná podpora ze strany rodin respondentů. Je zde také viditelný trend posouvání hranice těch, kteři se naučili s technologiemi pracovat ve svém zaměstnání, tato možnost byla druhá nejčastěji označovaná. Graf ukazuje, že i neformální vzdělávání není zcela marginální záležitostí, v součtu se jedná o 115 odpovědí. Odpovědi Jinak směřovaly ke kurzům organizovaným nějakou jinou institucí, specializovaným školením, samostudiu literatury apod. 


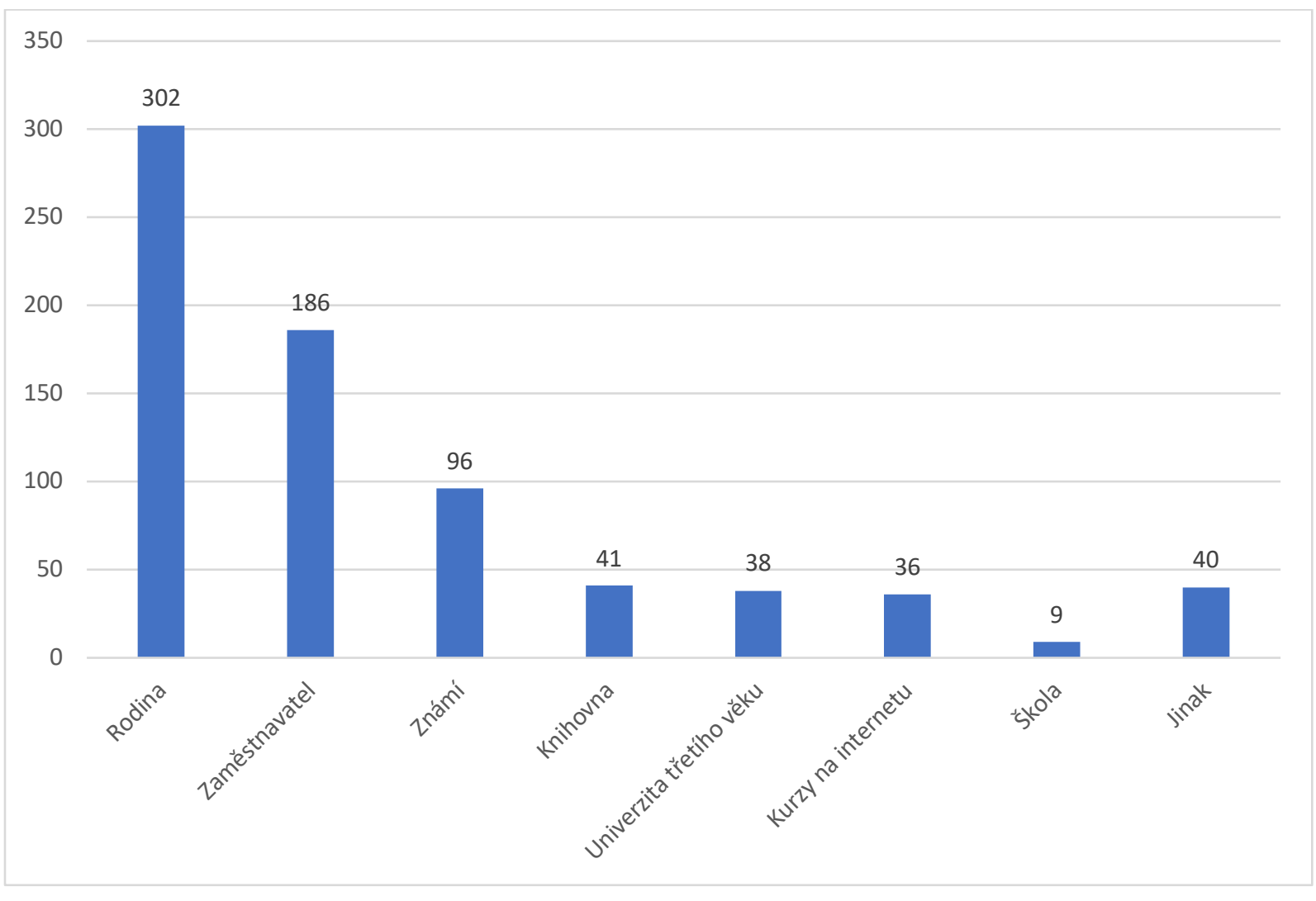

Graf 9 Pomoc v získáni dovednosti

Dotazník mapoval i zájem seniorů o další vzdělávání a zkoumal, zdali o takovou možnost respondenti stojí. Tato otázka byla jednou $\mathrm{z}$ nejdůležitějších vzhledem $\mathrm{k}$ cillům práce. $67,8 \% \mathrm{z}$ dotazovaných seniorů zřetelně svůj zájem o další vzdělávání projevilo a dalších 13,7 \% respondentů uvedlo, že zájem mají, ale kvưli různým překážkám se v tuto chvíli vzdělávat nemohou. Dohromady se tedy dostáváme $\mathrm{k}$ více než čty̌̌em pětinám seniorů, kteří mají zájem o vzdělávání. 


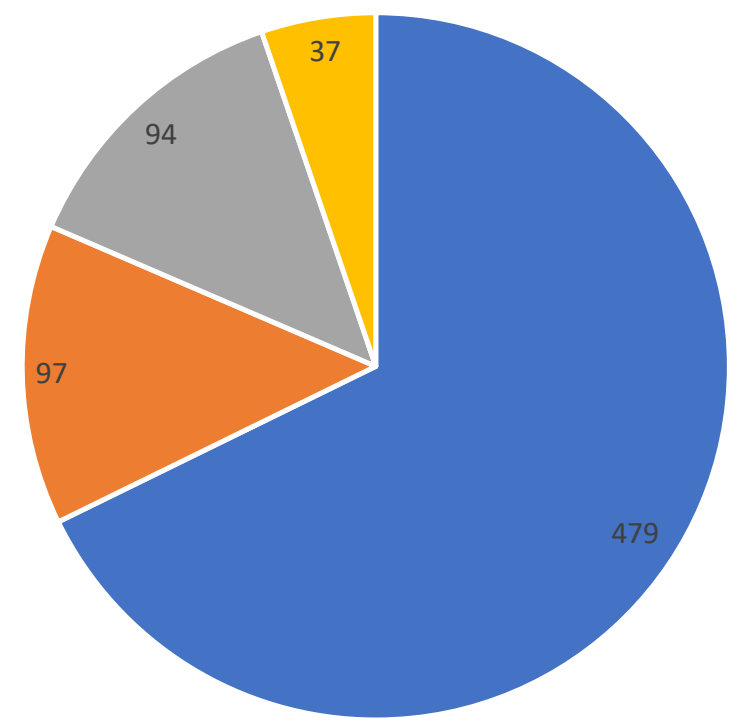

- Mám zájem se vzdělávat

• Vzdělávat bych se chtěl, ale není to z různých důvodů možné

- Nemám zájem se vzdělávat

- Je to jinak

Graf 10 Zájem o vzdèlávání

Další otázky zjišt’ovaly, prostřednictvím které instituce či organizace by se senioři nejraději vzdělávali, jakou preferují frekvenci návštěv vzdělávacích akcí a jaká by byla maximální částka, kterou by byli ochotni zaplatit. Z výsledků výzkumu vyplynulo, že senioři jako formu svého vzdělání preferují online kurzy (40,8 \%), následuje vzdělávání na univerzitách třetího věku (39,9\%) a vzdělávání prostřednictvím knihoven (35,5\%). Ty ostatně mají respondenti ve své blízkosti - když odhadovali, v jaké vzdálenosti mají nebližší knihovnu, naprostá většina uváděla vzdálenost ve stovkách metrů do cca dvou kilometrů od svého bydliště.

Více než polovina $(53,2$ \%) respondentů by byla ochotna vzdělávat se několikrát za měsíc, další by uvítali pouze jednorázovou akci $(17,2 \%)$ a následovala frekvence několikrát za rok (14,4 \%). Za lekci v trvání devadesáti minut jsou senioři ochotni zaplatit částku v rozmezí 1-200 Kč (průměrně 50-100 Kč), jen $13 \%$ respondentů uvedlo, že by nebylo ochotno zaplatit nic. Pro knihovny v tom lze spatřit signál, že se nemusí bát organizovat ucelenější série vzdělávacích akcí, za které mohou vybírat i symbolické vstupné. 


\subsection{Témata}

Senioři, kteří odpověděli, že mají zájem se vzdělávat, následně odpovídali na otázky, které se týkaly již samotných témat. Jednalo se celkem o 613 osob (možnost pokračovat na výběr témat byla dostupná i pro účastníky, kteří na otázku zkoumající zájem o vzdělávání odpověděli Je to jinak). Témata byla rozdělena do sedmi kategorií, které byly stanoveny na základě provedených výzkumů, strategických dokumentů, dostupných šetření a také na základě osobních zkušeností s výukou seniorů. Každá kategorie obsahovala 4-10 možností, celkem bylo respondentům nabídnuto 46 témat a v každé kategorii také možnost Jiné. Témata v dotazníku byla prezentována velmi konkrétně, aby respondenti nemuseli dlouze přemýšlet nad tím, o co se jedná. Všechny otázky byly typu zvolit více možností, takže každý respondent mohl (ne)označit všechna témata dle svého zájmu.

První kategorií bylo ovládání softwaru, ve kterém se na prvních dvou místech s poměrně velkým odstupem umístilo ovládání Google nástrojů (Gmail, Google Disk atd.) a běžné ovládaní operačního systému Windows. Následovala práce s prohlížeči (Google Chrome, MS Explorer, Mozzila). Témata u konce tabulky velký zájem nenaznamenala, a to zejména oblast použití nástrojů jako je e-mail, Word, Excel a Power Point.

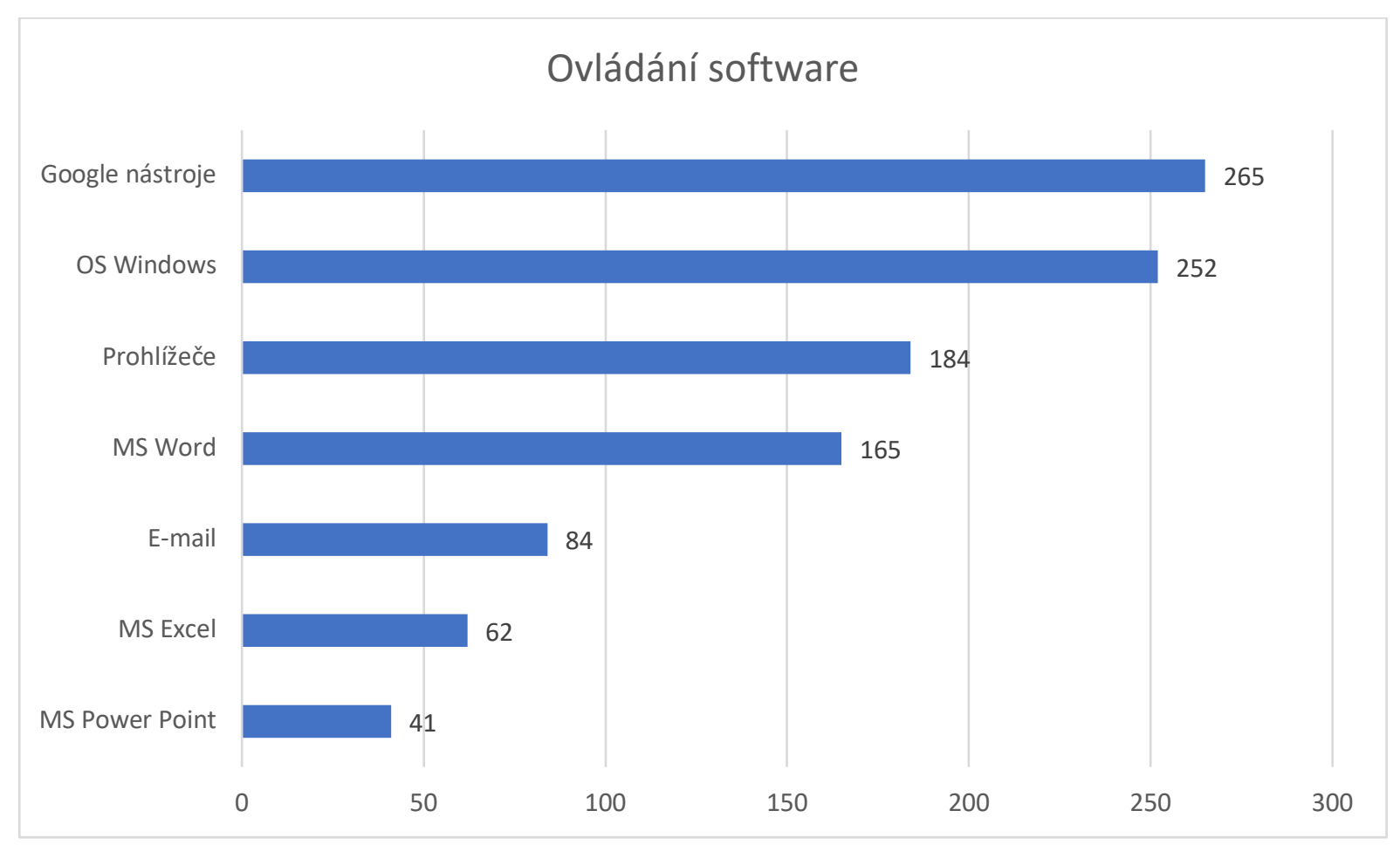

Graf 11 Témata: ovládáni software 
Druhá kategorie zahrnovala témata týkající se oblasti nakupování. Nejzajímavějším tématem v této kategorií se stal internetové bankovnictví, ale přesto je zájem o něj nižší než o nejsilnějšś témata v jiných kategoriích. Další témata byla zajímavá pro méně než jednu třetinu respondentů, zejména téma porovnávání cen se kupodivu nesetkalo s velkou pozorností.

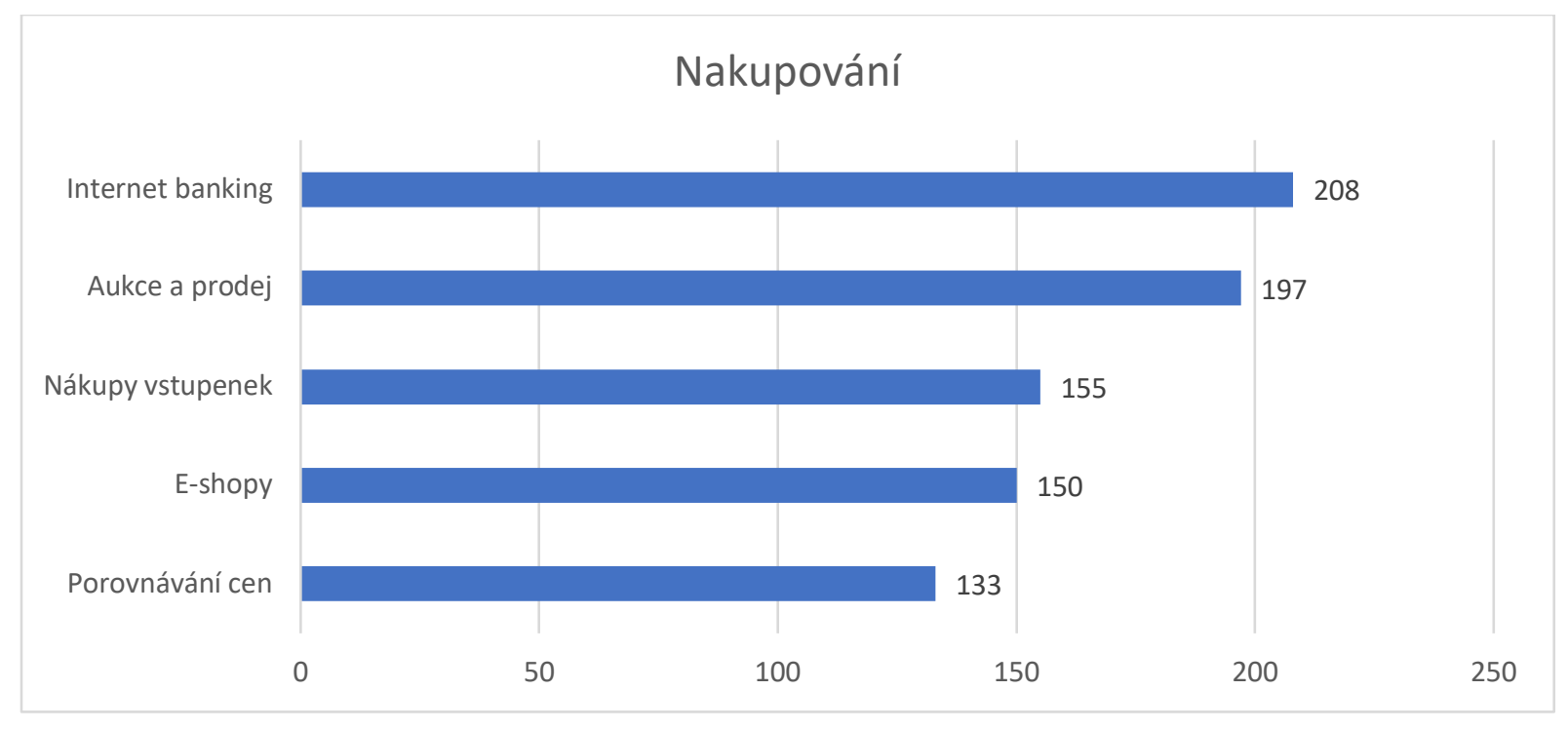

Graf 12 Témata: nakupování

V oblasti informační gramotnosti respondenty nejvíce zajímala oblast rozpoznání kvality informací, následována oblastí informační bezpečnosti. I ukládání a vyhledávání informací bylo pro respondenty př́nosné. $Z$ uvedených čísel jde dobře pozorovat, že $\mathrm{v}$ této kategorii byla první čtyři témata označena více než dvěstěkrát, což je více než třetina všech participantů.

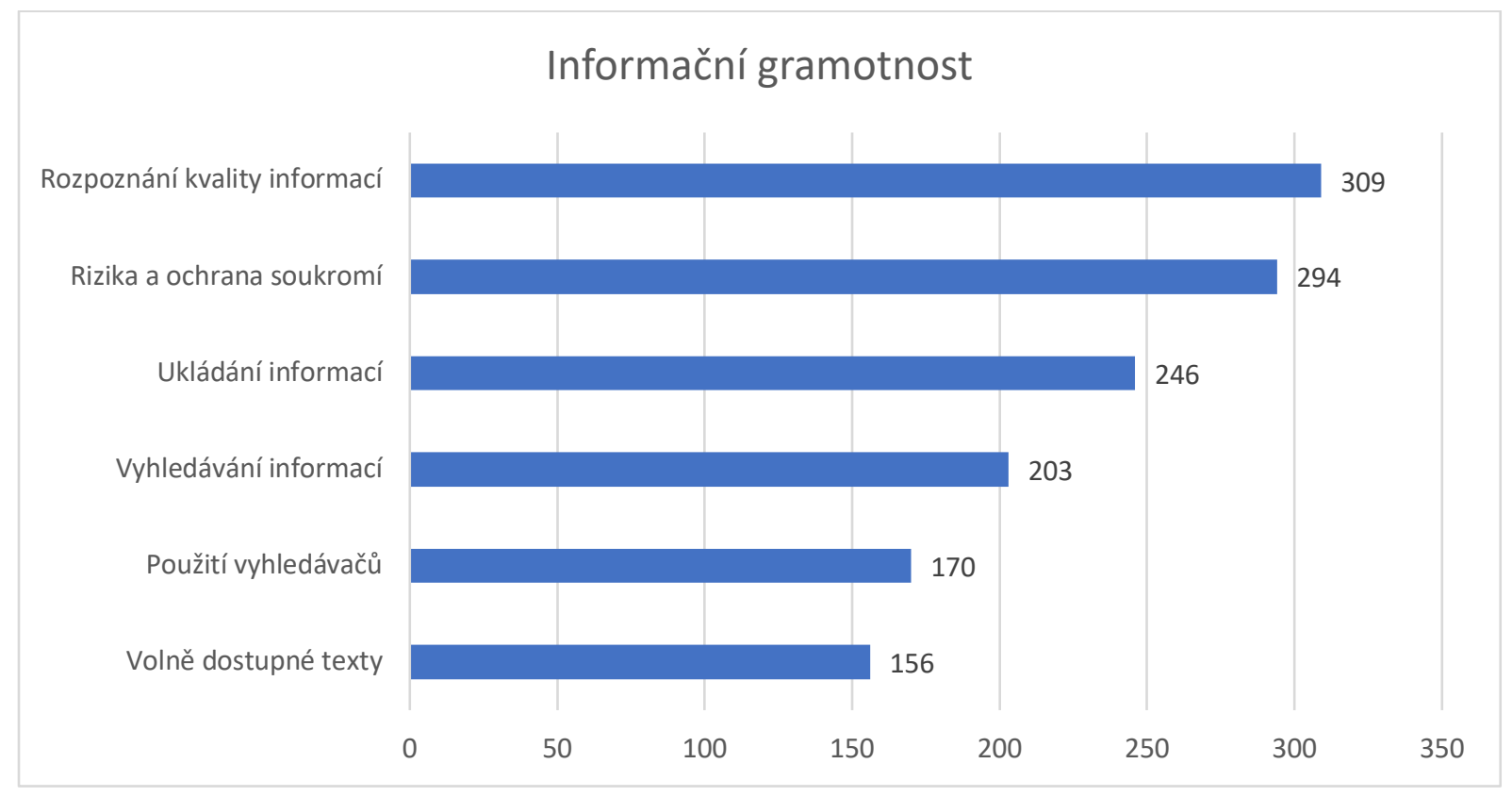

Graf 13 Témata: informačni gramotnost 
V další kategorii, týkající se komunikace, bylo poměrně často vybíráno telefonování. Oproti tomu seznamování se přes internet je pro seniory oblast, ve které se vzdělávat př́liš nechtějí. Sociální sítě a chatování získaly přes sto hlasů, nicméně oproti tématům z předchozí kategorie Informační gramotnosti je to poměrně slabý výsledek.

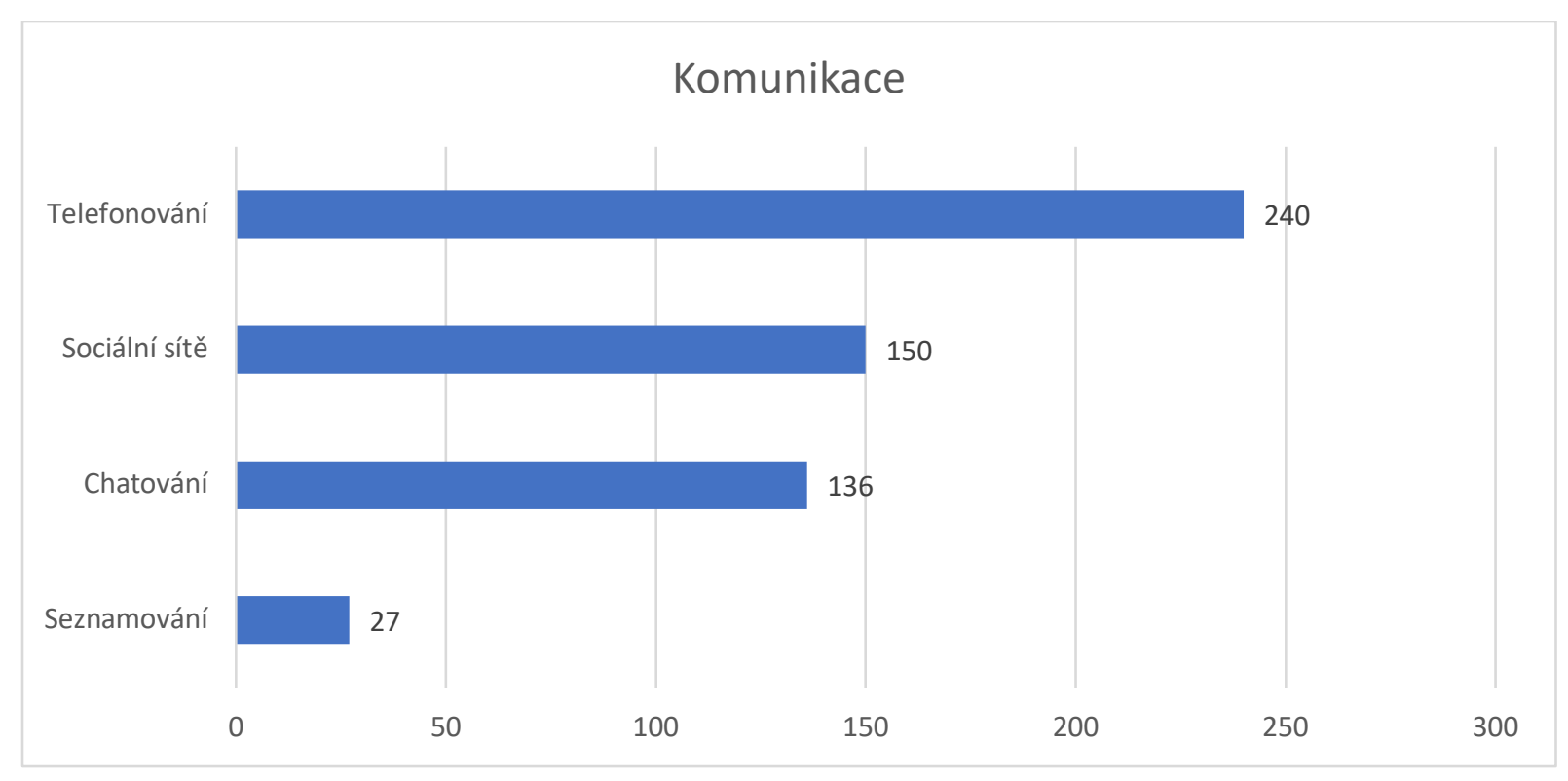

Graf 14 Témata: komunikace

Kategorie cestování obsahovala osm témat, dvakrát více než kategorie komunikace. Senioři nejčastěji volili téma online překladačů (Google Translator apod.). Práce s mapami nebo vyhledávání a prohližzení umění online také patří k tématům, ve kterých by chtěli více vzdělávat. Nižší zájem byl o vyhledávání ubytování, letenek nebo taxislužby.

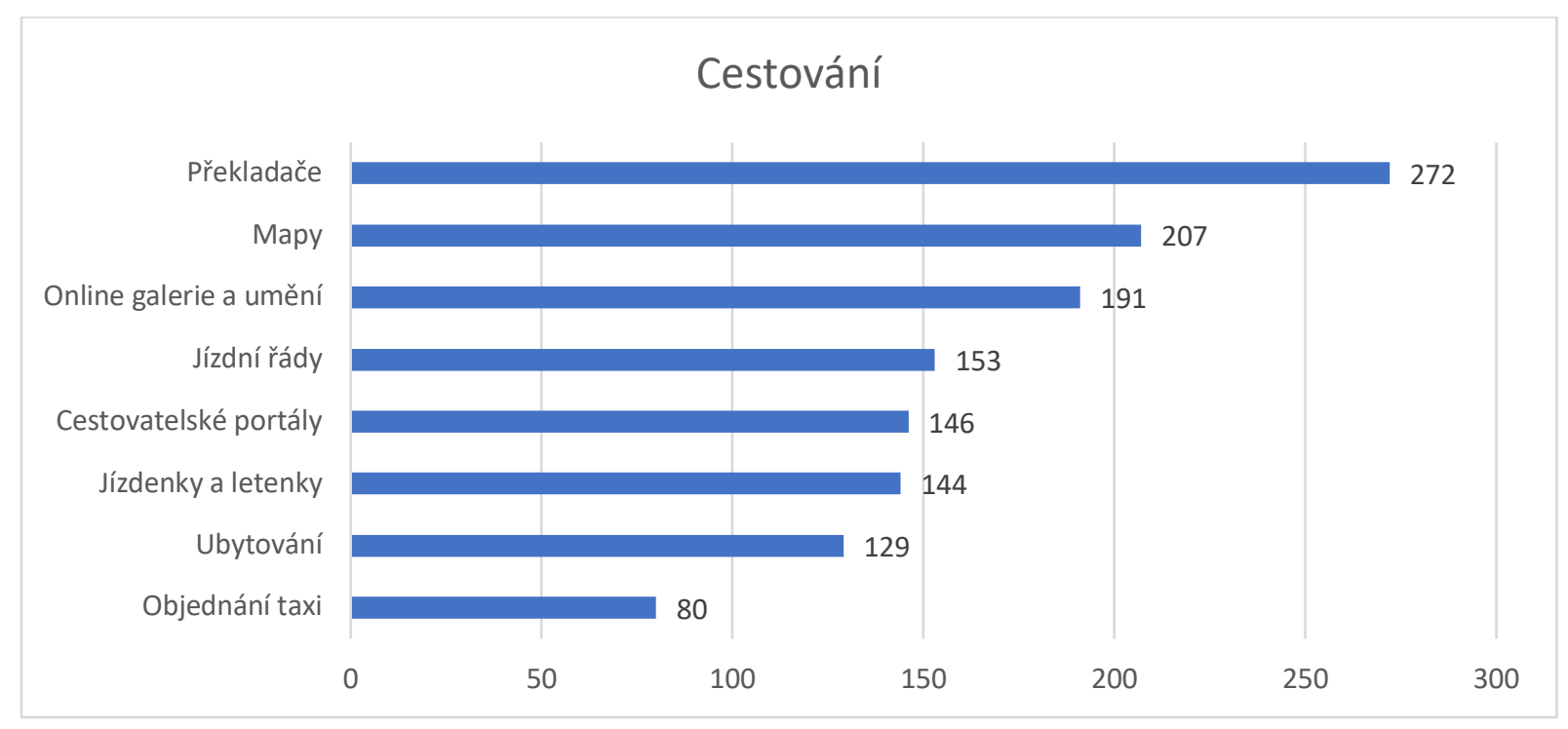

Graf 15 Témata: cestování 
Témata z kategorie tvorby obsahu jsou jednoznačně pro seniory nejzajímavější. Práci s fotografiemi dokonce zvolila více než polovina z možných respondentů, a stalo se tak tématem, ve kterém se respondenti chtějí vzdělávat nejvíce. Podobně je tomu i u stahování obrázků, tvorby různých grafických materiálů a práce s videem. Jen téma publikování vlastních textů nebo materiálů na internetu není pro respondenty až tak přitǎlivé.

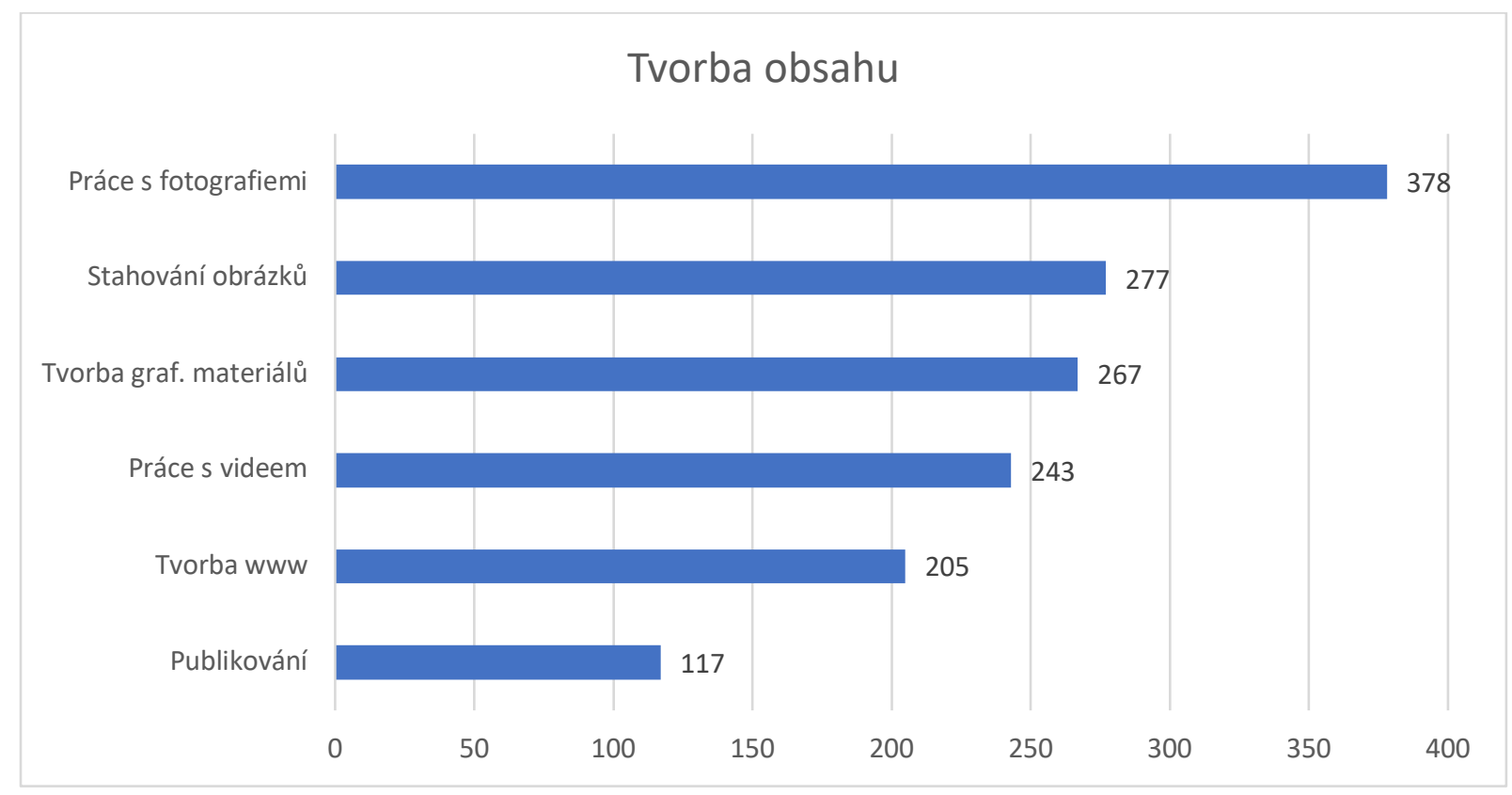

Graf 16 Témata: tvorba obsabu

Do kategorie Různé byla zařazena témata, která se tematicky do jiné kategorie zařadit nedala. Jak je vidět $\mathrm{z}$ dalšího grafu, $\mathrm{v}$ této kategorii se objevilo druhé nejvíce označované téma, a to práce s informačními zdroji používanými pro tvorbu rodokmenů. To je shodou okolností oblast, kterou v poslední době začaly knihovny do nabídky vzdělávacích aktivit více zařazovat. Také téma online vzdělávání bylo často vybíráno, na rozdîl od hraní her, online sázení a vyhledávání stránek s erotickým obsahem. 


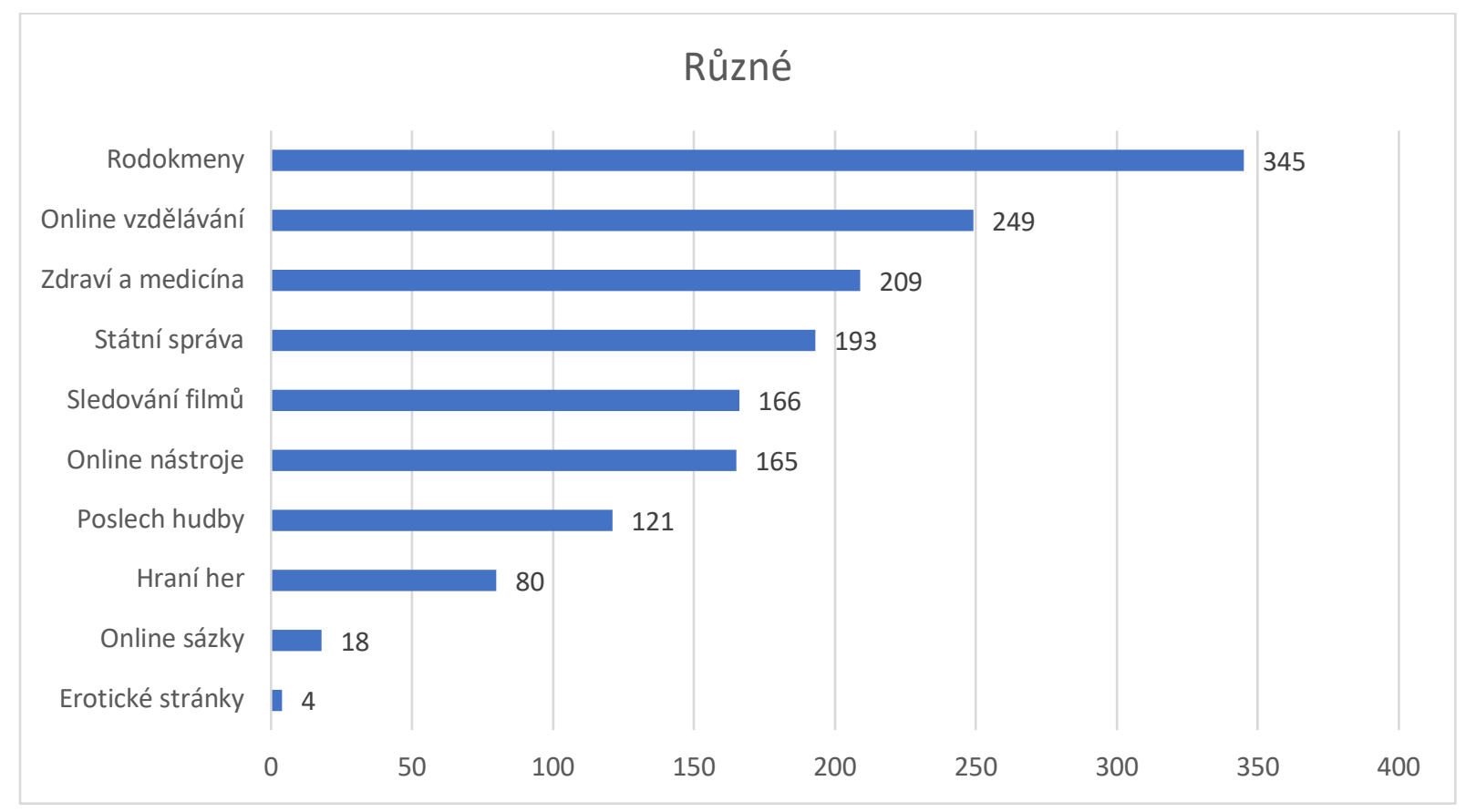

Graf 17 Témata: rĩné

Níže uvedený graf ilustruje zájem o témata celkově dle daných kategorií, kdy podle průměrného zájmu respondentů lze konstatovat, že senioři mají mnohem vyšší zájem o vzdělávání v oblastech tvorby obsahu a informační gramotnosti než v oblasti ovládání softwaru. Tento graf byl vytvořen srovnáním všech kategorií $\mathrm{v}$ relativních číslech, kdy byl zprůměrován zájem o témata $\mathrm{v}$ jednotlivých kategoriích a následně převeden do procentuálních hodnot.

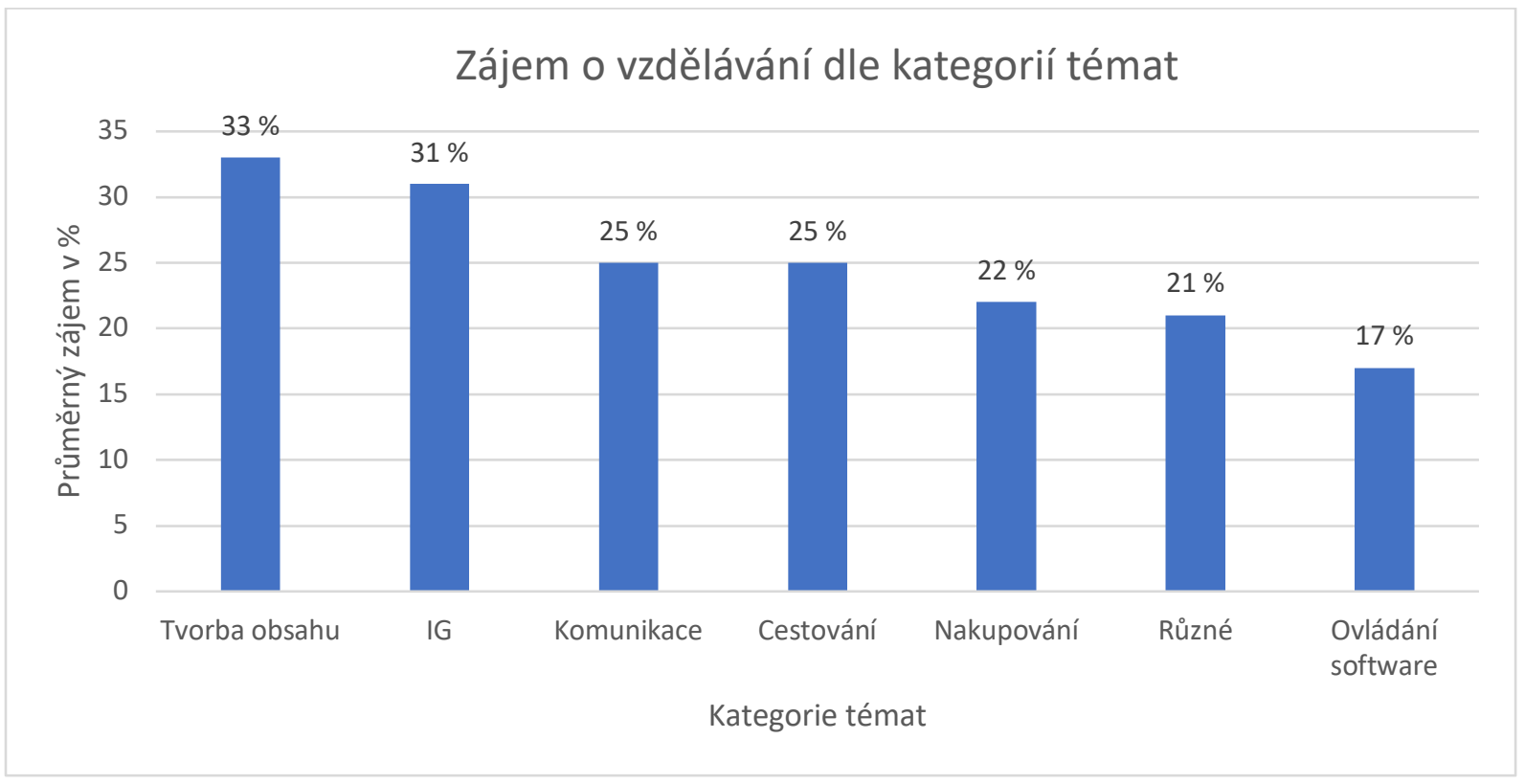

Graf 18 Zäjem o kategorie 
Pokud seřadíme témata napříč všemi kategoriemi dle vyjádřeného zájmu, ta, která byla označena minimálně třetinou všech respondentů, přináší odpověd’ na hlavní výzkumnou otázku, ve kterých tématech se senioři chtějí vzdělávat. Stala se podkladem pro vzdělávací lekce, které jsou popsány v další části práce.

Největší zájem mají respondenti o práci s fotografiemi, ve smyslu jejich ukládání, stahování a zejména úpravy. Tato dovednost nabývá na významu zejména ve spojení s chytrými telefony, pomocí kterých se dá rychle a jednoduše fotit. Senioři, jak zaznělo i v rozhovorech, sice umí pomocí telefonu fotit, ale potom neumí fotografie přenášet mezi jednotlivými zařízeními, neví, jak je zmenšit, neznají programy na jejich úpravu apod. Jak je vidět v grafu, na dalších pozicích se umístila témata, která s prací s fotografiemi úzce souvisí, a to je stahování obrázků, částečně i tvorba grafických materiálů a ukládání materiálů do počítače. Z nejžádanějších témat tvoří tyto dovednosti celou jednu třetinu.

Dalším tématem, které bylo ovšem do výzkumu zařazeno až na základě pilotáže, je téma genealogie, ve smyslu využití informačních zdrojů pro tvorbu rodokmenů. Tento zájem lze pričítat dostupnosti digitalizovaných materiálů, zejména matrik, a také zájmu starších lidí o svou minulost.

Poněkud překvapivým zjištěním je, že s velmi vysokým zájmem se setkala i témata rozpoznání kvalitních informací a informační bezpečnosti. Lze to vysvětlit narůstajícím objemem informací, ve kterém se senioři musí orientovat, a také tím, že tato cílová skupina si není v použínání internetu tolik jistá.

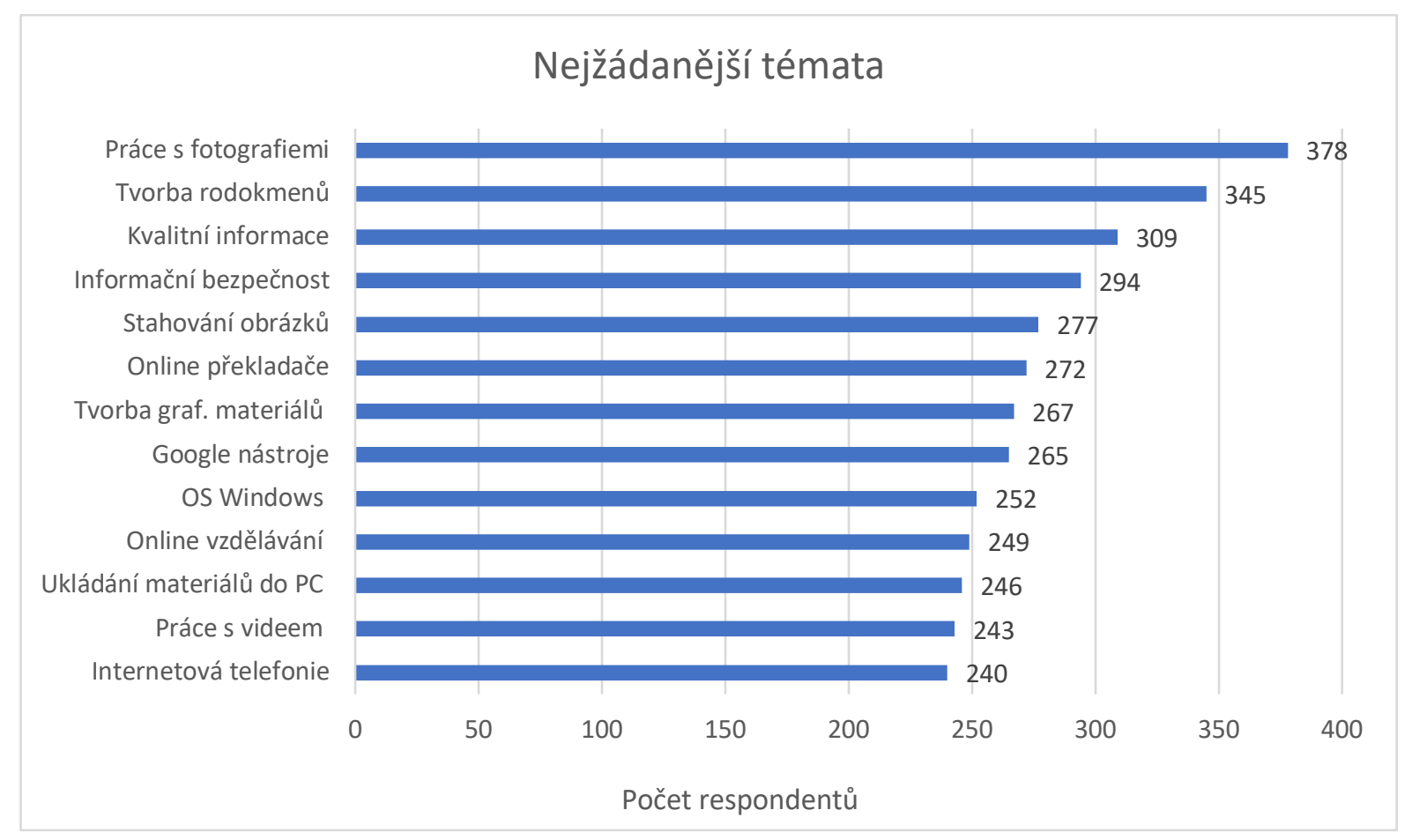

Graf 19 Nejžádanèjš̀ témata

$\mathrm{Na}$ opačné straně se umístila témata, která senioři nepovažují za zajímavá pro své vzdělávání, což může být dáno tím, že tato témata již znají (e-mail), nebo nepocit’ují žádnou potřebu v nich být vzděláváni (erotické stránky, hraní her apod.). Je ovšem možné, že některá z těchto témat mohli senioři vnímat jako príliš choulostivá a zdráhali se je označit, což může být prípad vyhledávání erotických stránek nebo seznamování. 


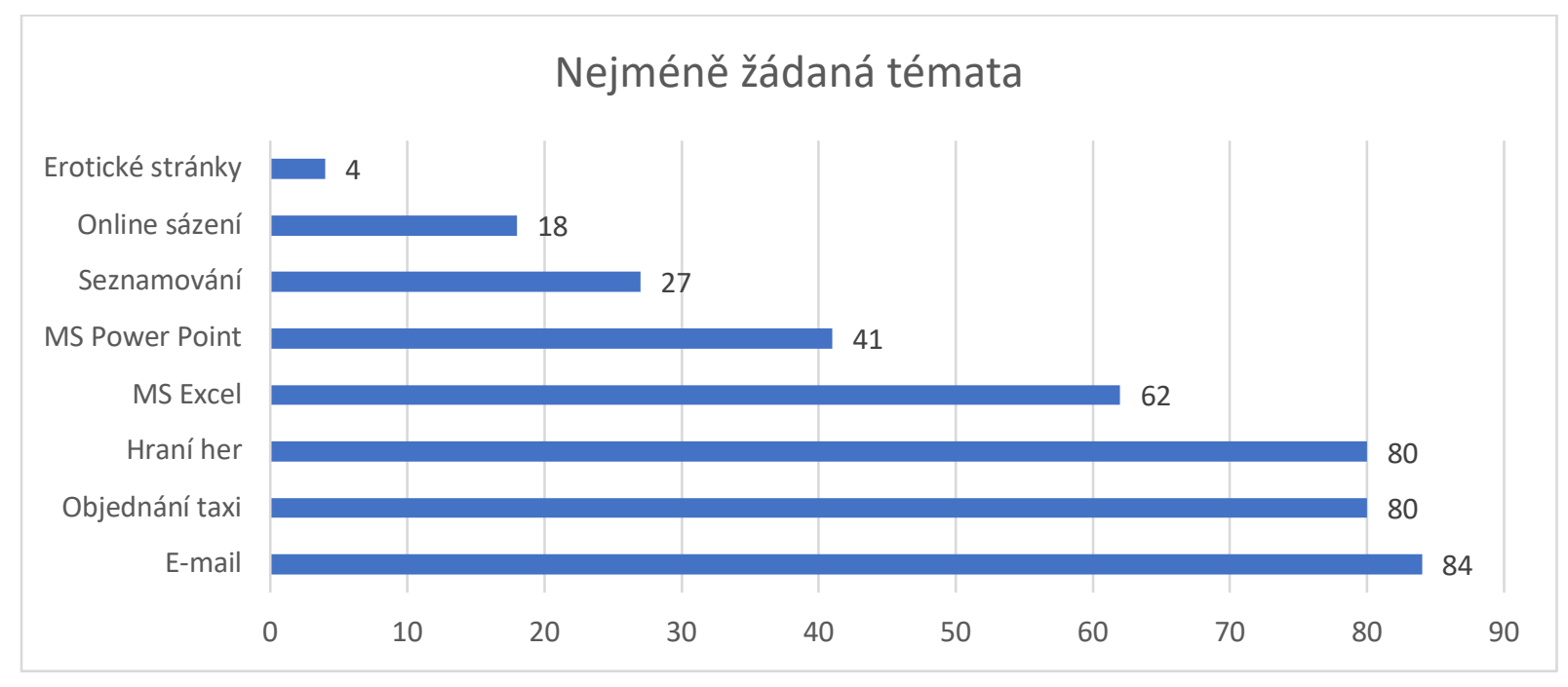

Graf 20 Nejméné žádaná témata

\section{Shrnutí výsledků}

Kvantitativní šetření přineslo mnoho zajímavých zjištění, týkajících se českých seniorů, jejich kompetencí v oblasti informační gramotnost, zájmu o vzdělávání a preferencí témat.

Hlavní hypotéza, která př̌edpokládala, že oblasti, ve kterých se chtěji senioři vzdělávat, souvisí častěji s prací s obsahem než s ovládáním nástroje, se potvrdila. Témata, která spadají do práce s obsahem, byla pro respondenty jednoznačně zajímavější než témata, která se týkají ovládání technologií. Současně se ukázal i zájem o témata související s oblastí informační gramotnosti, která zahrnuje právě dovednost práce $\mathrm{s}$ technologiemi a internetem.

Témata, která vykazovala velkou míru zájmu z hlediska vzdělávání, jsou často mezi dovednostmi, ve kterých respondenti deklarovali nižší míru sebedůvěry v jejich používání nebo uváděli, že tyto činnosti nedělají. Patrné je to třeba na dovednosti práce s fotografiemi, která v kompetencích patřila mezi ty, které senioři ovládají nejméně, a v tématech zájmu se objevila na prvním místě. Senioři tedy jeví vyšší zájem o vzdělávání v tématech a dovednostech, které př́liš neovládají nebo zatím nepoužívali. To potvrzují i Špatenková a Smékalová ve své publikaci zabývající se edukací seniorů (Špatenková, 2015).

Senioři své kompetence $\mathrm{v}$ oblasti informační gramotnosti hodnotí jako velmi uspokojivé. Zejména $\mathrm{v}$ tom smyslu, že z nabídky kompetencí jim v podstatě žádná, kromě dovedností voblasti tvorby obsahu a rozpoznání kvalitní informace, nedělá větší problém. To může být způsobeno narůstající mírou jejich informační gramotnosti, jak potvrzují i některé výzkumy zveřejněné v publikaci Sociologie stář̌ a seniorì (Sak, 2012). Dalším faktorem může být i vyšší míra sebevědomí seniorů při hodnocení jejich dovedností v práci s ICT a internetem, na kterou poukazuje Gonzáles (2012).

Rozdíly v hodnocení se projevují i dle věku seniorů, kdy mladší seniơ̌i (65-75 let) hodnotí své kompetence lépe, než senioři starší (76+). Je to dáno určitě i faktem, že mnozí z nich se s internetem potkali již během svého aktivního pracovního života. Další stále pracují a internet musí používat více a k sofistikovanějším 
úkonům než senioři starší. Některé kompetence senioři neznají nebo nepoužívají, což také ovlivnilo výsledné hodnocení.

Naopak se ukázalo, že senioři, kteří se naučili používat technologie s pomocí rodiny, hodnotí své současné dovednosti lépe. Podpora ze strany rodinných př́islušníků je tedy důležitým faktorem ovlivňujícím př́stup seniorů k internetu a ICT, což naznačil i kvalitativní výzkum a upozorňují na to i některé zahraniční výzkumy, zkoumající práce seniorů s ICT (González-Oñate, 2015). Vliv okolí respondentů na jejich adaptaci práce s internetem a ICT je tedy signifikantní. Bez této pomoci by se obešel jen málokdo ze zkoumaného vzorku. Tento vliv bude pochopitelně do budoucna slábnout a těžko v tuto chvíli odhadovat, jak a s čím bude $\mathrm{v}$ seniorském věku potřebovat poradit generace, která se už do doby technologií narodila. $\mathrm{V}$ tu chvíli budou výsledky těchto výzkumů překonány, jako napríklad tvrzení, že internet vstoupil do života seniorů až za jeho vrcholem (Sak, 2012).

Výsledky kvantitativního šetření se i v mnoha jiných ohledech potkaly s výsledky kvalitativního šetření (Zadražilová, 2017). Např́íklad v tom, že senioři často v rozhovorech zmiňovali, že jim dělá problém práce s fotografií, organizace dokumentů do složek, ukládání atd. Tyto činnosti v dotazníku často zařazovali mezi témata, ve kterých by se chtěli vzdělávat.

Také se potvrdil trend přeposilání emailů, který senioři vzpomínali v rozhovorech (Zadražilová, 2017). Data z dotazníku ukázala, že senioři zcela souhlasís tvrzením, že jim nedělá problém někomu předat elektronicky informaci (534 respondentů), respektive přeposlat obrázek či fotografii (525 respondentů). Tento fenomén se objevil i v jiných výzkumech, jako byl třeba výzkum Starci na netu (Kopecký, 2018), kdy autoři zjistili, že s přibývajícím věkem se rozšiřuje počet uživatelů internetu, kteří přes mail přeposilají spamy a hoaxy.

Výsledky šetření také ukázaly, že senioři obecně mají velký zájem se vzdělávat, at' už prostřednictvím knihoven, nebo dalších institucí. To potvrzuje i aktuální stoupající počet studentů U3V, v roce 2018 jich studovalo již více než 50000 (Keményová, 2019) a zájem stále roste. Narůstající trend v počtů účastníků také uvádí Virtuální univerzita třetího věku (VU3V, 2019), jejîž semináře jsou z velké části realizovány prostřednictvím sítě knihoven. Bohužel nejsou k dispozici data, která by uváděla počty návštěvníků (seniorů) vzdělávacích lekcí organizovaných knihovnami. Vzhledem ke stoupajícímu počtu vzdělávacích akcí v knihovnách obecně (Richter, 2014) se dá předpokládat, že roste i počet účastníků z této cílové skupiny. Senioři, kteří jsou ochotni chodit na akce opakovaně, také častěji preferovali možnost vzdělávání prostřednictvím U3V než prostřednictvím knihoven. Souvisí to pravděpodobně s komplexní nabídkou a organizací univerzit třetího věku, kdy jejich frekventanti navštěvují přednášky pravidelně, každý týden v semestru. Knihovny mají většinou nastavený jiný režim.

Vysoké procento participantů, kteří deklarovali svůj zájem vzdělávat se nebo se v minulosti vzdělávali, ovšem také úzce souvisí s atypickou (pro tuto věkovou skupinu) výší jejich dosaženého vzdělání. Jak uvádí

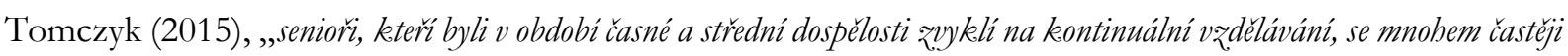

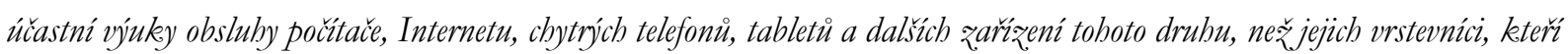
ve srovnatelném obdobi neparticipovali na formálních, neformálních či informálních vždèlávacich aktivitách". Na vztah mezi 
výší dosaženého vzdělání a účast v neformálním vzdělávání upozorňuje i Rabušic, autor kapitoly Senioř a jejich v₹̨elelávání (Rabušicová, 2008), a odvolává se na výsledky svého výzkumu, který podpořil hypotézu, že se zvyšujícím se vzděláním respondentů roste míra participace na vzdělávacích akcích a plány na participaci v budoucnu. „Platí totiž, že ti, kdo se zúčastnili v minulosti, plánují také úćasti v budoucnosti (...) a naopak, ti, kedo $v$ minulosti žádný kurz nenavstévovali, neuvažuji o tom ani do budoucnosti“ říká Rabušic a vyvozuje, že ,lze formulovat

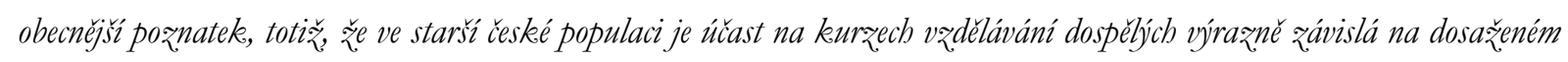

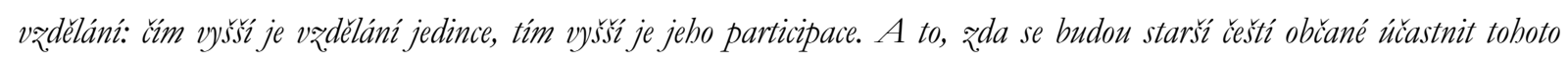

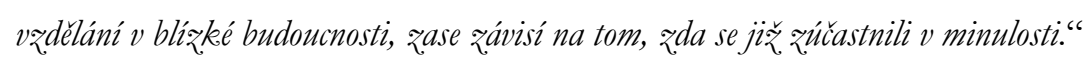

Nejdůležitější částí výzkumu bylo mapování témat. Potvrzení hypotézy, že senioři budou mít větši zájem o témata z oblasti tvorby obsahu než o témata z oblasti ovládání softwaru, nebylo príliš překvapivé. Tento trend se projevil i u jiných, zejména zahraničních výzkumů (Wu, 2015), (Llorente-Barroso, 2015). Podobná zjištění také uvádí např́klad Český statistický úřad (ČSÚ, 2017a).

Knihovny a další instituce tedy mohou bez obav uskutečnit lekce týkající se práce s fotografiemi, různých online nástrojů, Google nástrojů, práce s informačními zdroji pro tvorbu rodokmenů, rozpoznání kvalitních informací či oblasti informační bezpečnosti. Toto jsou témata, o která mají senioři zájem a která je mohou přilákat do knihoven spíše než nabídka lekcí na MS Word nebo MS Excel. Knihovny by ale měly zaměřit svou nabídku na tuto cílovou skupinu promyšleněji a zkusit nabídnout ucelenější vzdělávací cykly. K tomu by jim měla pomoct i navržená metodika, dostupná v publikaci V žlélávací lekce pro seniory: metodická prřručka (Zadražilová, 2019).

\section{Dedikace}

Publikace vznikla v rámci Institucionální podpory na dlouhodobý koncepční rozvoj výzkumné organizace - Moravská zemská knihovna v Brně.

The volume was funded by Institutional support for long term conceptual development of research organization (the Moravian Library) by Czech Ministry of culture. 


\section{Použitá literatura}

ČSÚ. (2017). Senioři [Online]. In Čské statistický úrad. Retrieved from https://www.czso.cz/csu/czso/seniori

ČSÚ. (2017a). Senioři v mezinárodním srovnání 2017 [Online]. In Český statistický úrad. Retrieved from https://www.czso.cz/csu/czso/seniori-v-cr-v-datech-2017

ČSÚ. (2018). Složení obyvatelstva podle pohlaví a jednotek věku k 31.12. 2018 [Online]. In Český statistický úrad. Retrieved from https://vdb.czso.cz/vdbvo2/faces/cs/index.jsf?page=vystupobjekt\&ds $=\mathrm{ds} 373 \& \mathrm{z}=\mathrm{T} \& \mathrm{f}=\mathrm{TABULKA} \& \mathrm{pvo}=\mathrm{DEMD} 001 \& \mathrm{o}=$ false $\mathrm{c}=\mathrm{v} 3 \sim 2 \_$RP2018MP12DP31\&str $={ }_{\mathrm{v}} 4 \# \mathrm{w}=$

ČSÚ. (2012). Úroveň vzdělání obyvatelstva ČR podle výsledků sčítání lidu v roce 2011 [Online]. In Český statistický úrad. Retrieved from

https://www.czso.cz/documents/10180/20536250/17023214a03.pdf/80a3d112-1f5b-4708-b0de-

b2c364a0065a?version $=1.1$

González, A., Ramírez, M. P., \& Viadel, V. (2012). Attitudes of the Elderly Toward Information and Communications Technologies [Online]. Educational Gerontology, 38(9), 585-594. https://doi.org/10.1080/03601277.2011.595314

González-Oñate, C., Fanjul-Peyró, C., \& Cabezuelo-Lorenzo, F. (2015). Use, Consumption and Knowledge of New Technologies by Elderly People in France, United Kingdom and Spain [Online]. Comunicar, 23(45), 19-28. https://doi.org/10.3916/C45-2015-02

Keményová, Z. (2019). Zájem o univerzity třetího věku roste, studuje už 50 tisíc seniorů [Online]. Universitas: Magazin Vysokých Škol. Retrieved from https://www.universitas.cz/tema/2702-zajem-o-univerzity-tretihoveku-roste-studuje-uz-50-tisic-senioru

Kočí, J. (2012). Cesty informaci ke senioruim (Diplomová práce). Brno.

Kopecký, K., Szotkowski, R., Kožíšek, M., \& Kasáčková, J. (2018). Starci na netu 2018: Výzkumná zpráva [Online]. In Wwn.upol.cz (pp. 1-23). Olomouc: Univerzita Palackého v Olomouci. Retrieved from https://www.starcinanetu.cz/vyzkum_vysledky.pdf

Llorente-Barroso, C., Viñarás-Abad, M., \& Sánchez-Valle, M. (2015). Internet and the Elderly: Enhancing Active Ageing [Online]. Comunicar, 23(45), 29-36. https://doi.org/10.3916/C45-2015-03

Mazurová, H., \& Houšková, Z. (Eds.). (2016). Rovný př̌stup: knibovna prátelská k senioruim: metodická príručka pro práci knihoven se seniory. Praha: Národní knihovna České republiky - Knihovnický institut. 
Miovský, M. (2003). Přručka k provádèni výbèru metodou sněhové koule (Snowball sampling). Praha: Úřad vlády České republiky.

MPSV. (2015). Strategie digitální gramotnosti ČR na obdobi 2015 ǎ̌2020. Česko: Ústřední knihovnická rada ČR. Retrieved from http://files.ukr.knihovna.cz/200000190-55d7557cc6/Strategie_digitalni_2015.docx

Novotná, I. (2013). Děti a senioři [Online]. Duha, 27(1). Retrieved from http://duha.mzk.cz/clanky/detiseniori

Quick, S., Prior, G., Toombs, B., Taylor, L., a Currenti, R. (2013): Cross-European survey to measure users' perceptionsof the benefits of ICT in public libraries (funded by the Bill and Melinda Gates foundation). [Online]. Retrived from

https://digital.lib.washington.edu/researchworks/bitstream/handle/1773/22718/Final\%20Report\%20\%20Cross-European\%20Library\%20Impact.pdf

Rabušicová, M., \& Rabušic, L. (Eds.). (2008). Učime se po celý život?: o vadělávání dospèlých v České republice. Brno: Masarykova univerzita.

Richter, V. (2014). Jak navštěvujeme veřejné knihovny [Online]. Čtenár, 66(2). Retrieved from http://ctenar.svkkl.cz/clanky/2014-roc-66/2-2014/tema-jak-navstevujeme-verejne-knihovny-1231632.htm

Sak, P., \& Kolesárová, K. (2012). Sociologie stárí a seniorů. Praha: Grada.

St. Jean, B., Rieh, S. Y., Kim, Y. -M., \& Yang, J. Y. (2012). An analysis of the information behaviors, goals, and intentions of frequent Internet users: Findings from online activity diaries [Online]. First Monday, 17(2). Retrieved from http:// firstmonday.org/ojs/index.php/fm/article/view/3870/3143

Stluková, I. (2015). České veřejné knihovny jako instituce celoživotního vẓdeláváni se zaměrením na seniory (Diplomová práce) [Online]. Praha. Retrieved from https://is.cuni.cz/webapps/zzp/detail/150867

Špatenková, N., \& Smékalová, L. (2015). Edukace seniori: geragogika a gerontodidaktika. Praha: Grada.

Tomczyk, Ł. (2015). Senioři ve světě nových médií a fenomén digitálního vyloučení v zemích Visegrádské čtyřky [Online]. E-Pedagogium: Nezávislý Odbormý Časopis Pro Interdisciplinární Výzkeum V Pedagogice, S Obledem Na Pedagogiku, Speciálni Pedagogiku A Didaktiky Obori, 2015(3), 83-95. Retrieved from http://old.pdf.upol.cz/fileadmin/user_upload/PdF/e-pedagogium/2015/e-Pedagogium_32015online.pdf

Van Deursen, A. J. A. M., \& Mossberger, K. (2018). Any Thing for Anyone? A New Digital Divide in Internet-of-Things Skills [Online]. https://doi.org/10.1002/poi3.171 
Wu, Y. -H., Ware, C., Damnée, S., Kerhervé, H., \& Rigaud, A. -S. (2015). Bridging the digital divide in older adults: a study from an initiative to inform older adults about new technologies [Online]. Clinical Interventions In Aging, 193-. https://doi.org/10.2147/CIA.S72399

Zadražilová, I. (2019). Vzdělávací lekce pro seniory: metodická príručka [Online]. Brno: Flow. Retrieved from http://eknihy.knihovna.cz/static/files/vzdelavaci-lekce-pro-seniory-metodicka-prirucka.pdf

VU3V: Virtuální univerzita třetího věku [Online]. (2019). Retrieved May 18, 2019, from https://esenior.czu.cz/

\section{Poznámka o autorovi}

Iva Zadražilová vystudovala obor Informační studia a knihovnictví na KISK FF MU v Brně, kde také několik let působila. V současné chvíli dokončuje doktorské studium oboru Informační věda na FF UK, jehož součástí je práce na výzkumech seniorů a jejich práci s internetem a ICT. Její specializací, které se dlouhodobě věnuje, je oblast informační gramotnosti, vzdělávání a metodologie tvorby odborných textů. Nyní se pohybuje mezi Brnem a Prahou a svůj pracovní čas dělí mezi několik aktivit. Je zaměstnána jako akademický pracovník na soukromé vysoké škole AMBIS a učí studenty základům práce $s$ informacemi a metodologii odborné práce. Současně také působí v Moravské zemské knihovně, kde je zodpovědná za vzdělávání knihovníků z celé republiky v práci s portálem Knihovny.cz. V neposlední řadě spolupracuje s centrem ELPIDA jako lektor vzdělávacích lekcí pro seniory.

E-mail: iva.zadrazilova@mzk.cz 